\title{
Nano-Biosensing Platforms for Detection of Cow's Milk Allergens: An Overview
}

\author{
Monika Nehra ${ }^{1, \dagger}{ }^{,}$Mariagrazia Lettieri ${ }^{2, \dagger}$, Neeraj Dilbaghi ${ }^{1}$, Sandeep Kumar ${ }^{1, *}$ and \\ Giovanna Marrazza ${ }^{2, *(D)}$ \\ 1 Department of Bio and Nano Technology, Guru Jambheshwar University of Science and Technology, \\ Hisar-Haryana 125001, India; ssmonikanehra@gmail.com (M.N.); ndnano@gmail.com (N.D.) \\ 2 Department of Chemistry "Ugo Schiff”, University of Florence, Via della Lastruccia, \\ 350019 Sesto Fiorentino (Fi), Italy; mariagrazia.lettieri@unifi.it \\ * Correspondence: ksandeep36@yahoo.com or sandeep2417@gjust.org (S.K.); \\ giovanna.marrazza@unifi.it (G.M.) \\ + Authors with equal contribution.
}

Received: 31 October 2019; Accepted: 16 December 2019; Published: 19 December 2019

\begin{abstract}
Among prevalent food allergies, cow milk allergy (CMA) is most common and may persist throughout the life. The allergic individuals are exposed to a constant threat due to milk proteins' presence in uncounted food products like yogurt, cheese, and bakery items. The problem can be more severe due to cross-reactivity of the milk allergens in the food products due to homologous milk proteins of diverse species. This problem can be overcome by proper and reliable food labeling in order to ensure the life quality of allergic persons. Therefore, highly sensitive and accurate analytical techniques should be developed to detect the food allergens. Here, significant research advances in biosensors (specifically immunosensors and aptasensors) are reviewed for detection of the milk allergens. Different allergic proteins of cow milk are described here along with the analytical standard methods for their detection. Additionally, the commercial status of biosensors is also discussed in comparison to conventional techniques like enzyme-linked immunosorbent assay (ELISA). The development of novel biosensing mechanisms/kits for milk allergens detection is imperative from the perspective of enforcement of labeling regulations and directives keeping in view the sensitive individuals.
\end{abstract}

Keywords: allergens; immunosensors; aptasensor; electrochemical sensor; optical sensor

\section{Introduction}

In recent decades, the increased prevalence of food allergy has posed challenges to both food industry and clinical allergology. The European Academy of Allergology and Clinical Immunology (EAACI) has defined the term 'food allergy' [1]. Food allergy can be defined as abnormal immune system reaction after eating a certain food. The specific components of the food are responsible for these allergic reactions in sensitized subjects. Adverse food reactions can be categorized into toxic as well as non-toxic reactions, where non-toxic reactions are non-immune-mediated reactions and more common than toxic reactions. These can involve reaction to particular substances (like intolerance to lactose) as well as enzyme defects (like vasoactive amines). The immune-mediated reactions are affecting millions of people in terms of life-threatening reactions. Food allergy is exclusively due to immunoglobulin E (IgE)-mediated reactions. The involved food does not necessarily adversely affect the all non-allergic individuals. The food allergy symptoms can be observed from skin rashes (like mild urticaria) to life-threatening reaction (like anaphylactic shock) [2]. In the Western world, diagnosed food allergies affect approximately $1-2 \%$ of the total population. The greatest prevalence of 
food allergy, up to $8 \%$, has been reported in younger children ( $<3$ years of age). The complete and official list of allergens has also been provided by the World Allergy Organization (WAO) [3].

Cow's milk allergy (CMA) has been identified as one of the most common and first cause of food allergy during early childhood because cow's milk is the first food introduced into the diet of an infant. After peanut and tree nuts, milk allergy is the third most common allergy among the eight major food allergens. It accounts for approximately $20 \%$ of all food-induced anaphylactic reactions based on a study in United States [4].

The CMA prevalence varies depending on different approaches that are used for diagnosis, geographical factor, and age differences in the studied population. As per the reports, CMA has been identified in $<0.5 \%$ of adults, $0.3 \%$ of older children, and $0.6-2.5 \%$ of preschoolers [5]. Over the past decade, the increasing incidences of worldwide CMA have been found for which the reasons are still unclear. The hypothesis behind these increased incidences has been reported in terms of hypersensitivities linked with increased cases of infant feeding with cow's milk over breast-feeding [6].

The persistence of CMA during adult life can force an individual for complete elimination of cow's milk from diet, since there is no treatment for CMA. However, the absence of milk in the diet can cause nutritional deficiency along with adverse effects over the growth of infants and/or children. The most common strategy to overcome this issue is to destroy/modify the structure of the milk allergens via food processing (i.e., heat treatment, enzymatic hydrolysis, fermentation, etc.) [7]. Cow's milk has more than 25 different proteins. The concentration of proteins in milk is around 30-35 grams per liter [8]. Out of these proteins, only a few have been identified to be allergenic for which the immune system reacts abnormally.

Currently, allergens identification has gained significant research interest due to increasing information about the sequence and structure of allergens. This information has permitted the development of databases (i.e., Allergome) [9] that provide biochemical, clinical, and molecular data of several allergens. Different milk allergen proteins and their characteristics are listed in Table 1. In particular, two fractions of raw skim milk can be produced through acidification at $\mathrm{pH} 4.6$ and $20^{\circ} \mathrm{C}$ such as: The coagulum that contains the casein proteins (i.e., $80 \%$ of the total milk proteins), and the lactoserum that contains whey proteins (i.e., $20 \%$ of the total milk proteins) $[10,11]$.

Table 1. Cow's milk allergenic proteins and their characteristics according to the World Health Organization and International Union of Immunological Societies (IUIS) allergen nomenclature [8,12].

\begin{tabular}{|c|c|c|c|c|c|}
\hline & Protein Name & $\begin{array}{c}\text { Allergen } \\
\text { Nomenclature }\end{array}$ & $\begin{array}{l}\text { Conc. in Milk } \\
\qquad\left(\mathrm{g} \mathrm{L}^{-1}\right)\end{array}$ & $\begin{array}{l}\text { Isoelectric } \\
\text { Point }\end{array}$ & $\begin{array}{c}\text { Number of } \\
\text { Amino } \\
\text { Acids/Molecules }\end{array}$ \\
\hline \multirow{4}{*}{$\begin{array}{c}\text { Casein proteins } \\
\quad(80 \%) \\
\left(\approx 5 \mathrm{~g} \mathrm{~L}^{-1}\right)\end{array}$} & $\alpha \mathrm{S} 1$-casein & Bos d 9 & $12.0-15.0$ & $4.9-5.0$ & 199 \\
\hline & $\alpha \mathrm{S} 2$-casein & Bos d 10 & $3.0-4.0$ & $5.2-5.4$ & 207 \\
\hline & $\beta$-casein & Bos d 11 & $9.0-11.0$ & $5.1-5.4$ & 209 \\
\hline & $\mathrm{K}$-casein & Bos d 12 & $3.0-4.0$ & $5.4-5.6$ & 169 \\
\hline \multirow{4}{*}{$\begin{array}{l}\text { Whey Proteins } \\
\qquad(20 \%) \\
\left(\approx 30 \mathrm{~g} \mathrm{~L}^{-1}\right)\end{array}$} & $\alpha$-Lactalbumin & Bos d 4 & $1.0-1.5$ & 4.8 & 123 \\
\hline & $\beta$-Lactoglobulin & Bos d 5 & $3.0-4.0$ & 5.3 & 162 \\
\hline & BSA & Bos d 6 & $0.1-0.4$ & $4.9-5.1$ & 582 \\
\hline & Immunoglobulins & Bos d 7 & $0.6-1.0$ & & \\
\hline
\end{tabular}

Casein proteins are the most abundant in the milk but there are lot of individuals with CMA induced by whey proteins [7]. The several protein variants can be easily degraded by proteolytic enzymes during digestion. The casein fraction precipitates in defined condition and consists of four different proteins with different percentages of the whole fraction such as (i) $\alpha$ S1-casein $(32 \%)$, (ii) $\alpha$ S2-casein (10\%), (iii) $\beta$-casein (28\%), and (iv) $\mathrm{k}$-casein (10\%). Here, $\alpha$ S1-casein has been found to be the most significant allergen of casein fraction [13]. 
Allergens of the whey fraction include (i) $\alpha$-lactalbumin ( $\alpha$-LA), (ii) $\beta$-lactoglobulin $(\beta$-LG), (iii) immunoglobulins (Ig), (iv) bovine serum albumin (BSA), and (v) traces of lactoferrin [8]. The whey proteins own tertiary, secondary, and quaternary structures (especially in case of $\beta$-LG). The presence of intramolecular disulfide bonds in whey proteins stabilize their structure; the 3D structure contributes to the allergenicity of the protein due to its importance in preserving the conformational epitopes. Moreover, the whey proteins are not phosphorylated proteins. Among these, the most allergenic proteins are $\beta$-LG (50\% of whey fraction) and $\alpha$-LA ( $25 \%$ of whey fraction).

$\beta$-LG is the main cow milk whey protein. It can also be found in milk of other mammalian species but not in human and rodent's milk. $\beta$-LG, being a small protein, possesses a molecular weight of $18.3 \mathrm{kDa}$ and also antioxidant activity. It consists of 162 amino acids (Table 1). It is associated with the lipocalin family, playing an important role in the transportation of small hydrophobic molecules such as cholesterol and vitamin D2 [14,15]. It also binds $\mathrm{Fe}^{2+}$ and $\mathrm{Cu}^{2+}$ ions along with hydrophobic ligands (such as retinol). There are two different genetic forms of $\beta$-LG: $\beta$-lactoglobulin A ( $\beta$-LGA) and $\beta$-lactoglobulin B ( $\beta$-LGB). The difference between these two forms of $\beta$-LG depends upon amino acids, i.e., Asp-64 and Val-118 in $\beta$-LGA, which are replaced by glycine and alanine, respectively, in $\beta$-LGB [16]. $\beta$-LG can form long stiff fibers under continuous heating at low ionic strength as well as low $\mathrm{pH}$. Under these conditions, $\beta$-LG solution forms a gel with a destabilized structure. The accountability of two disulphide bonds has been reported for high stability against acidic hydrolysis and proteases [8]. This property of $\beta$-LG enables preserving the structural integrity after digestion that allows its absorption via intestinal mucosa as well as further presentation to immunocompetent cells with high allergenic potential. This protein is majorly responsible for food allergy in approximately 60 to $80 \%$ of CMA patients [7].

The allergenic potential of $\alpha$-LA (Bos d 4) is due to the presence of a lot of epitopes, which selectivity bind IgE [7]. $\alpha$-LA is responsible for the lactose synthesis and also owns high stability due to the presence of four disulfide bridges and a high-affinity binding site for calcium that helps in stabilization of its secondary structure. BSA is present in small amounts in milk but nevertheless is an allergenic protein. Further, the allergenicity of BSA is due to the presence of the disulfide bridges that maintain the native antigenic determinants. Its biological role can be viewed in the transport, metabolism, several substances distribution, and further protection from free radicals [17].

The lactoferrin, a protein in the family of transferrin, is a glycoprotein. It is present in low quantities $(<1 \%)$ in milk of most of the species [18]. It functions as an antioxidant and free radicals' scavenger as well as defend the organisms against infections and inflammations that can be attributed to its ability of iron sequester from the environment [19]. Besides its involvement in detoxification processes, its antineoplastic effect is important in inhibiting the attachment of tumor growth factors. The allergenic activity of this protein is still not clear as the presence of IgE against other major milk allergens can also be found in milk-allergic individuals possessing lactoferrin-specific $\operatorname{IgE}[7,20]$.

The confusion of milk allergy with milk intolerance is common due to their similar symptoms. In comparison to allergy, the milk intolerance is not so dangerous; it can be specified as non-immunological reaction to certain component of milk that cause disorders in absorption, metabolism, or digestion. In case of milk allergy, the IgE-associated symptoms (relating to skin, respiratory system, and gastrointestinal tract) can be seen immediately or in sometime (about $2 \mathrm{~h}$ ) after milk intake. Sometimes, complex and systematic anaphylactic response can be observed due to involvement of one or more target organs [21,22]. Different standard gold diagnosis methods for CMA are available such as the double-blind, placebo-controlled oral food challenge (DBPCFC) and unblinded oral food challenge (OFC) [23]. Besides less rigoristic nature and validation of OFC tests, both tests suffer from several limitations in terms of inherent risk of anaphylaxis, time-/resource-intensive nature, inappropriate for clinical practice (especially in large epidemiologic studies), and also safety concerns in atopic children.

This review presents development of aptamers, biosensors, aptasensors for determination of allergen concentration in food matrix. The existing reviews mainly cover development of aptamers for allergens [24], biosensors for food allergens [25], confirmatory methods for allergens [26], and 
aptasensors for food analysis [27]. The present review is specifically designed to consider the cow milk allergens that can cause life-threatening anaphylactic reactions. In general, the use of biosensors in milk allergens detection offer many advantages in term of fast, repeatable, and highly sensitive approaches with great potential for full automation [28]. Furthermore, the biosensors (e.g., electrochemical and optical biosensors) have the potential to avoid the matrix treatment of via laborious techniques [29], supporting direct, real-time, and label-free detection (in the case of optical biosensors) for milk allergens detection. Furthermore, the use of the aptamers [27,30] and antibodies [31] as recognition element is emphasized to ensure the highly specific and sensitive performance of biosensors for the milk allergens detection. The commercially available biosensors are also summarized here as along with consideration of emerging challenges.

\section{Analytical Standard Methods for the Milk Allergens Detection}

In order to ensure the provision of food information to consumers, new legislation (i.e., the EU Food Information for Consumers Regulation 1169/2011) was introduced during December 2014 for all food businesses (i.e., deli counters, catering outlets, and bakeries). In this legislation, two different directives were incorporated for presentation and advertising the foodstuffs along with nutrition labelling. It was mandatory to provide allergen information on unpackaged food. The development of analytical techniques is of paramount importance to monitor the presence of allergens in both processed/unprocessed food keeping in view the public health implications and also labeling regulation.

In recent years, several guidelines have been published over diagnosis as well as treatment of CMA; however, the major contribution is of the World Allergy Organization (WAO) Diagnosis and Rationale for Action against Cow's Milk Allergy (DRACMA) [5,32]. The World Health Organization (WHO), the U.S. Food and Drug Administration (FDA), and other food safety management organizations are contributing in collaborative work for standardization of detection approaches for allergens and also to establish requirements for food labeling.

The detection techniques for food allergens differ in terms of basis of detection (biological or chemical), target analyte (DNA or proteins), phenomena of cross-reactivity of proteins, need for expertise, multitarget detection, and sensitivity to the specific allergens [25]. The thresholds of allergic reactions can be used as benchmark to specify the sensitivity limits of the sensors. The appropriate dose-distribution models have been reported to examine the minimal reactive doses to which maximum proportion of the people reacts [33]. Further, milk processing can also affect the several properties of the milk proteins such as increase in allergenicity due to pasteurization, decrease in antibody-binding capacity due to sterilization, and destruction of existing epitopes due to non-enzymatic glycation and denaturation [34].

The assessment of allergen labelling demands development of rapid, accurate, and cheap analytical techniques for sensing and quantification of milk allergens. The low concentration of allergens and also food matrices can be a problematic challenge in front of their detection. Most applied analytical approaches for milk allergens detection are: Protein-based methods and DNA-based methods [35,36]. These approaches differentiate in terms of the type of marker used for the allergen detection. In fact, DNA-based methods are based on specific DNA sequences that indicate the presence of the allergen. On the other side, protein-based methods are based on characteristic proteins (i.e., enzyme, antibody, etc.) as markers for detection of allergens. These are still most commonly exploited and available in different formats. These are based on antigen-antibody interactions including enzyme-linked immunosorbent assay (ELISA) [37,38], dipstick tests [39], and lateral flow devices (LFD) [40]. Furthermore, polymerase chain reaction (PCR) [41,42] and liquid chromatography-mass spectrometry (LC-MS) [26] platforms are mostly explored alternatives of antibody-based assays. Research efforts are directed for highly specific, sensitive, and rapid detection of allergens from the processed milk products [43-45]. Further, thermal and non-thermal processing of milk could make it hard to detect the proteins (i.e., responsible for milk allergy) using standard tests. However, the proteins of processed milk may still capable to cause runny eyes, itchy skin, wheezing, and other more serious symptoms [46]. In fact, few works 
reported the evaluation of immunoreactivity of pure whey and casein hydrolysates [47,48], but with limited application for detection of allergens from hydrolyzed milk proteins in various food matrices. Furthermore, heating and technological food processing could change the structure of target-protein or target-DNA structure compromising the final detection. Therefore, unambiguous identification and/or characterization of food allergens in different commercial products is essential to ensure the food safety.

\section{Biosensors in Detecting Food Allergens}

According to the International Union of Pure and Applied Chemistry (IUPAC), the definition of a biosensor can be given as "a self-contained integrated device, which is capable of providing specific quantitative or semi-quantitative analytical information using a biological recognition element (biochemical receptor or bioreceptor), which is in direct spatial contact with a transducer. The transducer is used to convert (bio)chemical signal resulting from the interaction of the analyte with the bioreceptor into an electronic one. The intensity of signal is proportional to analyte concentration" [49]. Different biomolecules (i.e., antibody, enzyme, cells, oligonucleotide sequence, etc.) and biomimetic molecules (molecular imprinted polymer, aptamer, etc.) have been used as bioreceptors.

Different types of devices have been reported depending on the modification transducer surface [50,51], bio-receptor employed (enzymes, antibodies, DNA) [52], immobilization strategy (covalent, non-covalent) [53,54], and detection mechanism (i.e., electrochemical, optical, etc.) [55]. The cross-reactivity of the biomolecules (i.e., immunoreactants and aptamers) to homologous proteins in milk of all ruminant species is the major factor that can affect the performance of biosensors. A similar protein composition can be seen between cow's and buffalo's milk; ewe's and goat's milk also have similar protein pattern to cow's milk but with reduced $\alpha$-casein fraction; camel's milk possesses different pattern than cow's milk in terms of several bands in caseins area and absence of $\beta$-LG [56]. Table 2 lists the allergens involved in cross-reactivity to milk proteins [7]. The cross-reactivity of antibodies was found between milk proteins (only caseins and $\beta-\mathrm{LG}$ ) of cow and others (i.e., ewe, goat, and buffalo) but not with camel's milk proteins [56]. In comparison to antibodies, the choice of specific aptamers can resolve the issue of cross-reactivity with other proteins of similar pattern [57]. In this section, both immunosensors and aptamer-based biosensors have been considered for the milk allergens detection (refer to Table 3).

For detection of milk allergens, the sample preparation is a very crucial step where extraction of the target analyte (i.e., specific DNA or proteins) without any kind of destruction or modification is carried out from the food matrices (like cheese, biscuits, cakes, etc.). For instance, sample preparation from cheese involves two different steps such as (i) mixing of cheese $(0.05 \mathrm{~g})$ with extraction buffer $(1 \mathrm{~mL})$ under shaking for $30 \mathrm{~min}$ at $60^{\circ} \mathrm{C}$ and (ii) centrifugation for $10 \mathrm{~min}$ at 10,000 rpm to obtain the standard sample solution [58]. Extraction conditions such as temperature or $\mathrm{pH}$ and other chemical interferences may significantly affect the stability and/or integrity of the target [28]. In the case of the raw milk, the research efforts confirmed the detection of allergens with simple buffer-diluted milk samples, i.e., UHT, pasteurized, human, and raw bovine milk [59-62]. An appropriate dilution with buffer solution enables a good result in allergenic proteins detection. On the other hand, it is possible to separate the whey protein from the casein one through the acidification of raw skim milk. In fact, depending on the allergen to be determined, the acidification procedure, followed by thermal shock and centrifugation, can help to increase the biosensor selectivity [1,63-66]. 
Table 2. Details of milk proteins of other species associated with cross-reactivity phenomena (adapted with permission from ref. [7]).

\begin{tabular}{|c|c|c|c|c|c|c|c|c|c|}
\hline Protein name & Buffalo & Goat & Sheep & Reindeer & Mare & Donkey & Mule & Camel & Pig \\
\hline$\alpha \mathrm{S} 1$-casein & Bub b 9 & Cap h 9 & Ovi a 9 & Not found & Equ c 9 & Not found & Not found & Cam d 9 & Sus s 9 \\
\hline$\alpha \mathrm{S} 2$-casein & Bub b 10 & Cap h 10 & Ovi a 10 & $\begin{array}{c}\text { Not } \\
\text { found.0 }\end{array}$ & Equ c 10 & Not found & Not found & Cam d 10 & Sus $\mathrm{s} 10$ \\
\hline $\mathrm{K}$-casein & Bub b 12 & Cap h 12 & Ovi a 12 & Not found & Equ c 12 & Not found & Not found & Cam d 12 & Sus $\mathrm{s} 12$ \\
\hline$\alpha$-Lactalbumin & Bub a 4 & Cap h 4 & Ovi a 4 & $\begin{array}{c}\text { Not } \\
\text { found } .0\end{array}$ & Equ c ALA & Not found & Not found & Cam d 4 & Sus s 4 \\
\hline BSA & Not found & Cap h 6 & Ovi a 6 & Not found & Equ c $3^{a}$ & Equ as 6 & Not found & Not found & Sus $\mathrm{s} 1^{\mathrm{a}}$ \\
\hline
\end{tabular}

Bub b: Bubalus bubalis; Cap h: Capra aegagrus hircus; Ovi a: Ovis aries; Ran t: Rangifer tarandus; Equ c: Equus caballus; Equ as: Equus asinus; Equ mu: Equus mulus; Cam d: Camelus dromedaries; Sus s: Sus scrofa domestica; ${ }^{a}$ : Present in WHO/IUIS official list of allergens.

Table 3. Different biosensing platforms for detection of milk allergens.

\begin{tabular}{|c|c|c|c|c|c|c|c|}
\hline $\begin{array}{l}\text { S. } \\
\text { No. }\end{array}$ & Type & Analyte & Biosensing Platform & $\begin{array}{l}\text { Transduction } \\
\text { Mechanism }\end{array}$ & $\begin{array}{l}\text { Detection } \\
\text { Limit }\end{array}$ & $\begin{array}{l}\text { Linearity } \\
\text { Range }\end{array}$ & Ref. \\
\hline 1 & \multirow{9}{*}{ 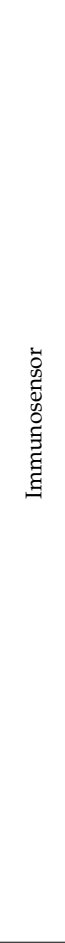 } & $\beta$-lactoglobulin & $\begin{array}{c}\text { Horseradish peroxidase labeled } \\
\text { antibody immobilized activated } \\
\text { carboxylic-modified magnetic } \\
\text { beads/carbon }\end{array}$ & Amperometric & $\begin{array}{l}0.8 \times 10^{-3} \\
\mu \mathrm{g} / \mathrm{mL}\end{array}$ & $\begin{array}{c}2.8-100 \times \\
10^{-3} \mu \mathrm{g} / \mathrm{mL}\end{array}$ & [67] \\
\hline 2 & & $\alpha$-lactoglobulin & $\begin{array}{l}\text { Horseradish peroxidase labeled } \\
\text { antibody immobilized activated } \\
\text { carboxylic-modified magnetic } \\
\text { beads/carbon }\end{array}$ & Amperometric & $\begin{array}{c}11 \times 10^{-6} \\
\mu \mathrm{g} / \mathrm{mL}\end{array}$ & $\begin{array}{c}37-5000 \times \\
10^{-6} \mu \mathrm{g} / \mathrm{mL}\end{array}$ & [62] \\
\hline 3 & & $\beta$-lactoglobulin & $\begin{array}{l}\text { Anti- } \beta \text {-lactoglobulin antibody } \\
\text { immobilized graphene/carbon }\end{array}$ & Electrochemical & $\begin{array}{c}0.85 \times 10^{-6} \\
\mu \mathrm{g} / \mathrm{mL}\end{array}$ & $\begin{array}{c}1 \times 10^{-6} \text { to } \\
100 \times 10^{-3} \\
\mu \mathrm{g} / \mathrm{mL}\end{array}$ & {$[65]$} \\
\hline 4 & & $\beta$-lactoglobulin & $\begin{array}{l}\text { Anti- } \beta \text {-lactoglobulin antibody } \\
\text { immobilized gold sensor chip }\end{array}$ & $\begin{array}{l}\text { Surface plasmon } \\
\text { resonance }\end{array}$ & $0.164 \mu \mathrm{g} / \mathrm{mL}$ & - & [68] \\
\hline 5 & & $\beta$-lactoglobulin & $\begin{array}{l}\text { Anti- } \beta \text {-lactoglobulin antibody } \\
\text { immobilized streptavidin coated } \\
\text { quantum dots/functional copolymer, } \\
\text { copoly (DMA-NAS) coated porous } \\
\text { alumina membrane }\end{array}$ & Polarimetry & $\begin{array}{c}33.7 \times 10^{-3} \\
\mu \mathrm{g} / \mathrm{mL}\end{array}$ & - & [69] \\
\hline 6 & & $\beta$-lactoglobulin & $\begin{array}{l}\text { Double-antibody sandwich } \\
\text { immunoassay }\end{array}$ & $\begin{array}{l}\text { Surface plasmon } \\
\text { resonance }\end{array}$ & $\begin{array}{c}5.54 \times 10^{-3} \\
\mu \mathrm{g} / \mathrm{mL}\end{array}$ & $\begin{array}{c}5-40 \times 10^{-3} \\
\mu \mathrm{g} / \mathrm{mL}\end{array}$ & {$[70]$} \\
\hline 7 & & $\alpha$-lactalbumin & $\begin{array}{l}\text { CdSe/ZnS quantum dots conjugated } \\
\text { with monoclonal antibodies }\end{array}$ & $\begin{array}{l}\text { Fluorescence-linked } \\
\text { immunosorbent } \\
\text { assay }\end{array}$ & $\begin{array}{l}0.1 \times 10^{-3} \\
\mu \mathrm{g} / \mathrm{mL}\end{array}$ & $\begin{array}{l}0.1 \text { to } 1000 \times \\
10^{-3} \mu \mathrm{g} / \mathrm{mL}\end{array}$ & [71] \\
\hline 8 & & $\begin{array}{c}\text { Casein and } \\
\text { Immunoglobulin G }\end{array}$ & $\begin{array}{l}\text { Integrated lab-on-a-membrane } \\
\text { foldable device using } \mathrm{Pb} \text { - and } \\
\mathrm{Cd} \text {-quantum dot tags }\end{array}$ & Electrochemical & $\begin{array}{c}0.04 \mu \mathrm{g} / \mathrm{mL} \\
\text { and } 0.02 \\
\mu \mathrm{g} / \mathrm{mL}\end{array}$ & $\begin{array}{l}0-5 \mu \mathrm{g} / \mathrm{mL} \\
\text { and } 0-2 \\
\mu \mathrm{g} / \mathrm{mL}\end{array}$ & {$[72]$} \\
\hline 9 & & Casein & $\begin{array}{l}\text { Rat basophilic leukemia-immobilized } \\
\text { graphene/carbon nanofiber/gelatin } \\
\text { methacryloyl nanocomposites-based } \\
\text { paper sensor }\end{array}$ & Electrochemical & $\begin{array}{c}3.2 \times 10^{-2} \\
\mu \mathrm{g} / \mathrm{mL}\end{array}$ & $\begin{array}{l}0.1 \text { and } 3.2 \\
\mu \mathrm{g} / \mathrm{mL}\end{array}$ & [73] \\
\hline 10 & \multirow{6}{*}{ 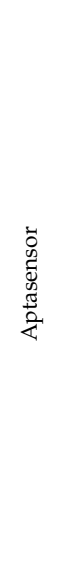 } & $\beta$-lactoglobulin & $\begin{array}{l}\text { Aptamers immobilized } \\
\text { graphene/carbon }\end{array}$ & Electrochemical & $\begin{array}{c}20 \times 10^{-6} \\
\mu \mathrm{g} / \mathrm{mL}\end{array}$ & $\begin{array}{c}100 \times 10^{-6} \\
\mu \mathrm{g} / \mathrm{mL} \text { to } \\
100 \times 10^{-3} \\
\mu \mathrm{g} / \mathrm{mL}\end{array}$ & {$[64]$} \\
\hline 11 & & $\beta$-lactoglobulin & $\begin{array}{l}\text { Aptamer functionalized } \mathrm{Fe}_{3} \mathrm{O}_{4} / \mathrm{cDNA} \\
\text { conjugated carbon dots }\end{array}$ & Florescence & $\begin{array}{c}37 \times 10^{-6} \\
\mu \mathrm{g} / \mathrm{mL}\end{array}$ & $\begin{array}{c}0.25 \times 10^{-3} \\
\text { to } 50 \times 10^{-3} \\
\mu \mathrm{g} / \mathrm{mL}\end{array}$ & {$[74]$} \\
\hline 12 & & $\beta$-lactoglobulin & 23-nucleotide aptamer-amphiphile & $\begin{array}{l}\text { Enzyme linked } \\
\text { apta-sorbent assay }\end{array}$ & $10 \mathrm{nM}$ & 5 to $0.01 \mu \mathrm{M}$ & [75] \\
\hline 13 & & $\beta$-lactoglobulin & $\begin{array}{c}\text { Aptamer coupled } \\
\text { poly(aniline-co-anthranilic } \\
\text { acid)/graphite }\end{array}$ & Electrochemical & $0.053 \mu \mathrm{g} / \mathrm{mL}$ & $\begin{array}{l}0.01 \text { to } 1.0 \\
\mu \mathrm{g} / \mathrm{mL}\end{array}$ & [76] \\
\hline 14 & & Lactoferrin & $\begin{array}{l}\text { Bivalent aptamer linked to fluorescein } \\
\text { isothiocyanate dye and silver } \\
\text { decahedral nanoparticles }\end{array}$ & $\begin{array}{l}\text { Fluorescence } \\
\text { polarization }\end{array}$ & $\begin{array}{l}0.1 \times 10^{-3} \\
\mu \mathrm{g} / \mathrm{mL}\end{array}$ & $\begin{array}{l}0.2 \times 10^{-3} \text { to } \\
25 \mu \mathrm{g} / \mathrm{mL}\end{array}$ & [77] \\
\hline 15 & & $\beta$-lactoglobulin & $\begin{array}{l}\text { Microfluidic paper-based device with } \\
\text { aptamer conjugated gold } \\
\text { nanoparticles/graphene }\end{array}$ & Colorimetry & $12.4 \mathrm{nM}$ & $\begin{array}{l}25 \mathrm{nM} \text { to } \\
1000 \mathrm{nM}\end{array}$ & {$[78]$} \\
\hline
\end{tabular}




\subsection{Immunosensors}

In immunosensors, the immunochemical antibody-antigen ( $\mathrm{Ab}-\mathrm{Ag})$ interactions are used as recognition elements. The sensitivities of the immunosensors is strongly dependent on the quality of antibody and transduction mechanism. Specifically, the capability of recombinant antibodies to be modified genetically offers several benefits in term of easy immobilization, excellent selectivity, and sensitivity. The biosensors combining the principle of solid phase immunoassay with magnetic beads (MBs) are ideal tools for immobilizing molecules like proteins (enzymes, antibodies, peptides, etc.) or nucleic acids. The immunoassays have been reported as versatile and powerful tool in several analytical and biotechnology applications $[79,80]$. Their use leads to improve the analytical performances of the biosensors (refer to Figure 1). Electrochemical magneto immunosensors based on sandwich approach are realized from Pingarrón's group for the detection of $\beta$-LG and $\alpha$-LA allergens $[62,67]$. The covalent immobilization of selected antibodies has been reported on carboxylic acid-functionalized magnetic beads (MBs) via amidic groups. The antibodies modified MBs were further incubated with sample solutions to capture the targets. After that, the affinity reaction with the secondary antibody (i.e., horseradish peroxidase-labeled) was carried out. The magnetically captured MBs over the surface of a screen-printed carbon electrode were utilized to examine the biorecognition event under amperometric measurements. The generated reduction current through hydroquinone $\mathrm{HQ} / \mathrm{H}_{2} \mathrm{O}_{2}$ system was further measured and analyzed. The immusensors were able to detect both $\alpha$-LA and $\beta-\mathrm{LG}$ retrieving a limit of detection (LOD) of $11.0 \times 10^{-6} \mu \mathrm{g} / \mathrm{mL}$ [62] and $0.8 \times 10^{-3} \mu \mathrm{g} / \mathrm{mL}$ [67], respectively. The magneto immunosensors were successfully applied in the milk samples analysis and their outcomes were further validated with commercial ELISA spectrophotometric kits. No doubt, the LOD of magnetoimmunosensor for $\beta$-LG was 10 times lower (i.e., $20 \times 10^{-6} \mu \mathrm{g}$ in $25 \mu \mathrm{L}$ sample) than that of commercial ELISA kit (i.e., $195 \times 10^{-6} \mu \mathrm{g}$ ), however the immunosensor showed remarkably faster detection process (i.e., about $60 \mathrm{~min}$ ) than the kit (i.e., 4 h) [67]. Further, in case of $\alpha$-LA detection, the immunosensor offered fast detection process (only $30 \mathrm{~min}$ ) than ELISA kit [62]. Therefore, the immunosensors are highly efficient to detect the lower proteins contents (i.e., up to $10^{-6} \mu \mathrm{g}$ ) in the milk samples. In case of processed milk samples (e.g., pasteurized milk), the protein contents decrease than raw milk samples (i.e., 3-4 g/L) [81]. This decrease can be attributed to native structural changes in the proteins due to heat treatments. Moreover, irreversible structural changes in proteins due to processing can also alter their recognition by specific biomolecules.

A label-free voltammetric immunosensor using graphene-modified screen-printed electrode has been reported for detection of $\beta$-LG [65]. The aqueous acidic solution was used for derivatization of the electrode via electrochemical reduction of 4-nitrophenyl diazonium cations (i.e., in situ generated), which is further followed by the reduction of the nitro groups to amines. Further, the $\beta$-LG antibodies were covalently immobilized by the amine groups over glutaraldehyde-activated working electrode surface. A linear decrease in differential pulse voltammetry (DPV) reduction peak current of $\left[\mathrm{Fe}(\mathrm{CN})_{6}\right]^{3-/ 4-}$ redox probe was observed with increased concentration of $\beta-\mathrm{LG}$, which tends to the antigen-antibody complexes formation on the electrode surface. This immunosensor offered a LOD of $0.85 \times 10^{-6} \mu \mathrm{g} / \mathrm{mL}$ and a linear detection range from $1 \times 10^{-6} \mu \mathrm{g} / \mathrm{mL}$ to $100 \times 10^{-3} \mu \mathrm{g} / \mathrm{mL}$ for $\beta$-LG standard solutions. Real samples (including cake, sweet biscuit, and cheese snacks) were also analyzed by the immunosensor, which confirmed the concentration of $\beta$-LG (i.e., 7.5, 7.47, and 87,330 $\mu \mathrm{g} / \mathrm{mL}$, respectively). The results of real samples were also validated with commercially ELISA method, i.e., 9.3, 7.7, and 92,300 $\mu \mathrm{g} / \mathrm{mL}$ for cake, sweet biscuit, and cheese snacks, respectively. 

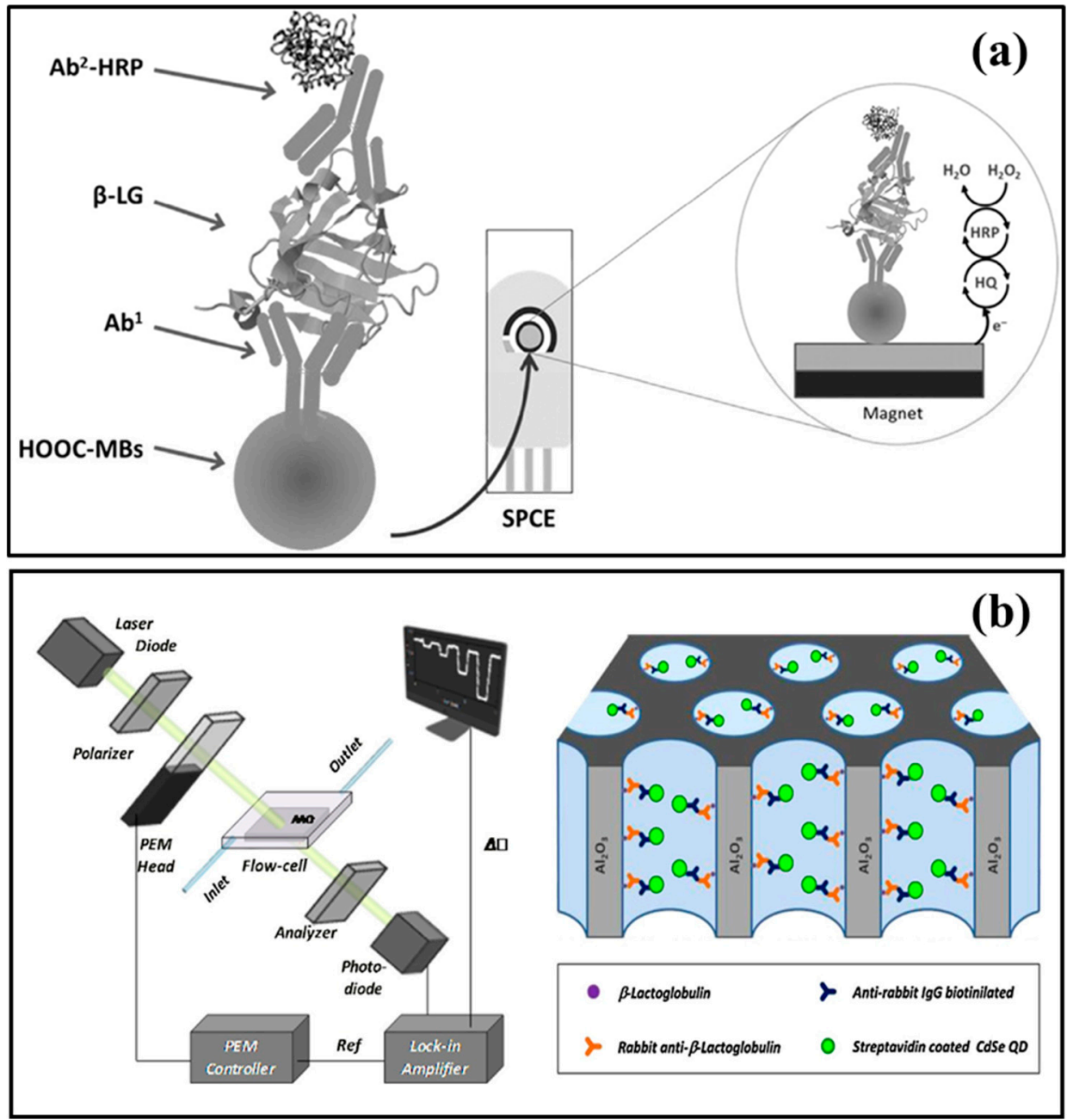

Figure 1. The most common immunosensors for milk allergens detection; (a) $\beta$-LG sandwich magneto immunosensor (reprinted with permission from ref. [67]) and (b) schematic layout of optical polarimetric platform to measure the phase retardation within the microporous alumina membranes carrying immunoassay for $\beta$-LG detection (reprinted with permission from ref. [69]).

Further, piezoelectric quartz crystal (QCM) sensors are also gaining considerable attention as competitive tool for characterization of biomolecular interactions as well as for bioanalytical assays [82,83]. In these sensors, the immobilization of bioreceptor is carried out over quartz crystal, which resonates due to the application of an external alternating electric field. Further, the biospecific reaction takes place between the two molecules interactive to each other, i.e., one free in solution and the other immobilized over the surface; this reaction can be examined in real time. Therefore, these biosensors are advantageous in terms of their simplicity of use, label free detection, and real-time monitoring. Ito et al. [68] demonstrated the analysis of $\beta$-LG using monoclonal antibodies and a flow-based QCM sensor that offered a LOD down to $1 \times 10^{-3} \mu \mathrm{g} / \mathrm{mL}$. However, QCM biosensor are facing some limitations in terms of sensitivity, specificity, and excessive interferences [84].

An immunosensor based on modified macroporous alumina membrane coupled with polarimetry was utilized to detect $\beta$-LG. Firstly, the membrane pore walls were coated with a functional copolymer, $\mathrm{N}, \mathrm{N}$-dimethylacrylamide- $\mathrm{N}$-acryloyloxysuccinimide for the $\beta$-LG immobilization (Figure 1). Then, the immuno-assay proceeded to bind with the primary as well as secondary antibody cognates, i.e., rabbit anti- $\beta$-LG and anti-rabbit IgG, respectively. Further, quantum dots coated with streptavidin were used as enhancers for the refractive index signal. This immunosensor offered a $3.7 \times 10^{-3} \mu \mathrm{g} / \mathrm{mL}$ 
$(25 \mathrm{pM})$ noise floor for individual measurements, or formal assay with an LOD of $33.7 \times 10^{-3} \mu \mathrm{g} / \mathrm{mL}$ (225 pM) [69].

The surface plasmon resonance (SPR) approach offers distinct benefits such as (i) flexibility and versatility and (ii) rapid, automated, and real-time analysis of diverse molecular interactions ranging from peptide-peptide and protein-protein to protein-cell interactions. Different optical biosensing approaches have been exploited for different applications in clinical, environmental, and food analysis [85-89]. SPR biosensors have also been developed for label-free and sensitive sensing of milk proteins $[65,66]$. Recently, an immunoassay based on SPR approach was reported for $\alpha$-casein detection in rinse water samples at cleaning in place (CIP) of food manufacturing [90]. The SPR sensor showed good sensitivity with a LOD of $57.8 \times 10^{-3} \mu \mathrm{g} / \mathrm{mL}$, comparable to ELISA. Further, SPR biosensor based on immunoassay has also been developed for $\beta$-LG detection [68]. The optimized SPR biosensor was successfully examined for its detection performance, offering excellent sensitivity with $0.164 \mu \mathrm{g} \mathrm{mL}{ }^{-1} \mathrm{LOD}$. An SPR method has also been reported for simultaneous and quantitative determination of different milk allergens such as $\alpha$-LG, $\beta$-LG, lactoferrin, immunoglobulin G, and BSA in raw as well as processed milk with six samples per assay [66]. Further, an SPR immunosensor has been developed for the simultaneous detection of $\beta$-LG and Ara h1 allergens [70]. The monoclonal antibodies (mAbs) developed against $\beta$-LG and Ara h1 were immobilized on the biosensing chip to capture the proteins from the sample solutions. SPR biosensing platform offered detection limits for $\beta$-LG and Ara h1 as 5.54 and $0.77 \times 10^{-3} \mu \mathrm{g} / \mathrm{mL}$, respectively. More recent SPR immunosensor was reported for determination of both common $\beta$-LG variants in bovine milk by Indyk et al. [91]. In this case, the temporal variability in the $\beta$-LG content was studied in pasture-fed cows' milk during both early lactation as well as production season.

Further, SPR assay was compared with (i) standard immunoassays (i.e., ELISA) for LF and IgG quantification in milk and whey and (ii) with HPLC for $\alpha$-LG, $\beta$-LG, and BSA estimation in whey with correlation coefficients of $R^{2}>0.97$ between these methods, except for IgG, which had $R^{2}=0.94$ [66]. In addition, the assay was applied to analyze the contents of individual whey proteins in different dairy fluids such as liquid whey samples, commercial milk powders, skim milk, and whole milk. Moreover, surface plasmon resonance imaging (SPRi) was applied for anti-bovine IgG sensing in both untreated human serum as well as milk, ranging from 0.1 to $1.0 \times 10^{6} \mu \mathrm{g} / \mathrm{L}$. The LOD was found $0.11 \times 10^{6} \mu \mathrm{g} / \mathrm{L}$ in diluted samples [92].

Further, microcantilever (MC)-based biosensing platforms have been applied for detection of various clinical targets [93]. However, only limited work is reported on the application of MC resonator array for determination of desired biomolecular analytes in the foodstuff. An immunosensor based on MC resonator arrays is reported by Ricciardi et al. [94] for $\beta$-LG detection. The developed sandwich immunoassay offered better LOD $\left(0.04 \times 10^{3} \mu \mathrm{g} / \mathrm{mL}\right)$ than commercial ELISA tests $\left(0.19 \times 10^{3} \mu \mathrm{g} / \mathrm{mL}\right)$ with the use of same biorecognition element [71].

Other strategies for sensitive voltammetric analysis of allergens involve the coupling of bioreceptors with novel features (i.e., coding and amplification) of inorganic nanocrystals in order to achieve a highly selective, sensitive, and simultaneous sensing of multiple protein targets. A competitive immunosensor was proposed by Kokkinos et al. [72] for bovine immunoglobulin G (bIgG) and bovine casein (CN) detection. The electrochemical devices are realized by screen-printed cell (SPC) with nylon membranes, symmetrically located on each side of SPC. Further enhancing the assay sensitivity, the graphite screen-printed electrode was modified with a bismuth citrate. The competitive immunoassay was performed using biotinylated antibodies labeled with $\mathrm{Cd}$ - and $\mathrm{Pb}$-based quantum dots conjugated with streptavidin. Upon dissolving these labels, the release of $\mathrm{Cd}(\mathrm{II})$ and $\mathrm{Pb}$ (II) was observed in the assay zones. After that, the two assay zones were folded over and brought in contact with electrochemical cell where anodic stripping voltammetric (ASV) was performed. The bismuth citrate reduces during the preconcentration step. Duplex ASV-QDs-based detection of both bIgG and CN was performed in milk samples yielding an LOD of $0.02 \mu \mathrm{g} / \mathrm{mL}$ and $0.04 \mu \mathrm{g} / \mathrm{mL}$, respectively. Further, the immunosensors have also been reported for reliable determination of IgGs from adulterated milk with colostrum or 
milk from other animals (i.e., goats, cows, and sheep). The electrochemical bioplatform based on antibody-conjugated magnetic beads offered excellent LODs of $0.66,0.74$, and $0.82 \times 10^{-3} \mu \mathrm{g} / \mathrm{mL}$ for caprine, bovine, and ovine IgGs, respectively [95]. The obtained detection limits are much lower than that of ELISA methodologies (i.e., between 0.7 and $1.95 \times 10^{-3} \mu \mathrm{g} / \mathrm{mL}$ ) for IgG detection. This bioplatform was successfully applied to different types of samples (i.e., diluted milk samples) such as (i) raw, pasteurized, and colostrum milk samples and (ii) milk samples from different animals and provided fast results, i.e., within $30 \mathrm{~min}$. The magnetic beads can offer several advantages in biosensing platforms such as easy functionalization, large surface area, improved sensitivity, matrix effect minimization, rapid assay kinetics, and easy control over location/transport with the help of a magnetic field $[96,97]$.

Due to recent advancements in smartphone and realization of new apps, many researchers focused their attention on the use of 'smart devices' in bioanalytical applications $[98,99]$. Recent research publications have successfully explored the feasibility of such smart devices for sensing of a wide range of targets in biological fluids [100-102]. The incorporation of smartphone technology with immunosensors have been explored for detection of numerous food allergens, however limited work is reported on milk allergens detection [103-106]. An amperometric biosensor based on an inhibitory immunoassay for detection of $\beta$-casein was reported by Molinari et al. [107]. For detection, eight electrochemical cells were integrated into a portable potentiostat, which is controlled by a smartphone via Bluetooth. The determination of $\beta$-casein in the $0-10 \mathrm{ppm}$ range was performed and an LOD of $0.173 \times 10^{3} \mu \mathrm{g} / \mathrm{mL}$ was achieved.

The mast cells have a natural ability to determine the presence of the food allergens and further produce proinflammatory responses. These offer an accurate and stable strategy mimicking the physiological conditions [108]. A new paper-based analytical device has been reported for the sensitive detection of casein [73]. The sensor utilized casein antibody-sensitized mast cells that were immobilized on graphene/carbon nanofiber/gelatin methacryloyl nanocomposite material-based electrode. The developed paper-based sensor using cells offered a range of linearity from 0.1 to $1 \mu \mathrm{g} / \mathrm{mL}$ of casein detection with an LOD of $3.2 \times 10^{-2} \mu \mathrm{g} / \mathrm{mL}$.

To determine the fraudulent substitution of goat milk along with its derivatives in bovine milk, a label-free immunosensor for real-time detection of k-casein based on broad-band Mach-Zehnder interferometry was proposed by Angelopoulou et al. [109]. The LOD of the assay was observed to be $0.04 \%(v / v)$ and the working range from 0.1 to $1 \%(v / v)$ of bovine in goat milk [110]. Other immunosensors include a surface-enhanced Raman scattering-based lateral flow strips for sensing of milk allergens [111]. Besides these advancements in immunosensors for faster allergen detection, all techniques based on antibodies (whether ELISA or immunosensors) suffer from difficulties in the analysis of processed food. In the case of processed food, the treatment and the processing of food matrix led to denaturation, hydrolysis, and conformational changes in proteins, due to which they cannot be recognized by antibodies properly [112]. Moreover, the quality of antibodies is also crucial for development of ultra-sensitive immunosensors.

\subsection{Aptasensors}

Aptasensor are affinity biosensors, in which aptamers are immobilized at the electrode surface and are used as the bioreceptor to selectively bind the target analyte. The binding event leads to change of electrical or optical analytical signal at transducer surface and therefore could be easily monitored. Nowadays, aptamers are replacing other biorecognition elements, especially antibodies with similar functionality due to enormous benefits in terms of more stability, easy and cheaper production, lasting longer, and availability of more modification choices [113-117]. Although the use of antibodies as biological reagents is very common, there, however, are several issues associated with antibodies such as ethical issues in their production inside animals, time-consuming process, and high-cost manufacturing. In spite of antibodies, aptamers are more stable over a good range of temperature and can be produced by in vitro chemical processes. Further, some aptamers have high specificity and 
affinity for target binding than antibodies. Moreover, they can be easily modified with new functional groups due to the possibility of reversible denaturation [118].

Over the past few decades, the significant work can be seen on production of aptamers against various targets via systematic evolution of ligands by exponential enrichment (SELEX) [30,114]. Especially for milk allergens, silver decahedral nanoparticles and fluorescence activated cell sorting (AgNPsFACS)-based SELEX has been reported for highly sensitive and specific screening of aptamers against respective milk allergens [119]. Some aptamers already screen targeting milk proteins (refer to Table 4).

Table 4. Screened aptamer sequences with binding affinity for milk allergens.

\begin{tabular}{|c|c|c|c|c|}
\hline $\begin{array}{l}\text { S. } \\
\text { No. }\end{array}$ & Aptamer Sequence & $\begin{array}{l}\text { Affinity Constant, } \\
K_{d}(\mathrm{nM})\end{array}$ & $\begin{array}{l}\text { Targeted Milk } \\
\text { Allergen }\end{array}$ & Ref. \\
\hline 1 & $\begin{array}{l}\text { CGACGATCGGACCGCAGTACCCACCCACC } \\
\text { AGCCCCAACATCATGCCCATCCGTGTGTG }\end{array}$ & $82 \pm 30$ and $80 \pm 26$ & $\begin{array}{l}\beta \text {-lactoglobulin A } \\
\text { and B }\end{array}$ & [64] \\
\hline 2 & 5'-GGGGTTGGGGTGTGGGGTTGGGG/3AmMO/-3' & $22 \pm 2$ & $\beta$-lactoglobulin & [75] \\
\hline 3 & $\begin{array}{l}\text { 5'-FITC-AGGCAGGACACCGTAACCGGTGC } \\
\text { ATCTATGGCTACTAGCTCTTCCTGCCT-3' }\end{array}$ & $28.78 \pm 7.20$ & lactoferrin & [77] \\
\hline 4 & $\begin{array}{l}\text { ATA CCA GCT TAT TCA ATT CGA CGA } \\
\text { TCG GAC CGC AGT ACC CAC CCA CCA } \\
\text { GCC CCA ACA TCA TGC CCA TCC GTG } \\
\text { TGT GAG ATA GTA AGT GCA ATC T }\end{array}$ & - & $\beta$-lactoglobulin & [78] \\
\hline 5 & $\begin{array}{l}\text { CGGTGCATCTATGGCTACTAGCTTTTCCT } \\
\text { GCCTATACTAC }\end{array}$ & $1.04 \pm 0.50$ & lactoferrin & [120] \\
\hline
\end{tabular}

Among food allergens detectable by aptasensors, only a few examples of aptasensors are reported in literature to detect different milk allergens (refer to Figure 2) [121,122]. An electrochemical disposable platform based on aptamer-coupled ploy(aniline-co-anthranilic acid) (PANI/PAA) deposited graphite electrode offered effective detection of $\beta$-LG via differential pulse voltammetry [76]. The LOD was found $0.053 \mu \mathrm{g} / \mathrm{mL}$ in $\beta$-LG-spiked milk samples. Eissa and Zourob [64] selected various aptamer sequences with high selectivity and specificity to both $\beta$-LG A and B with dissociation constants (Kds) of 82 and 80 $\mathrm{nM}$. The aptamer sequence selected for $\beta$-LG was immobilized on graphene-modified screen-printed carbon electrodes. The binding between the aptamer and the target was monitored via the square wave voltammetry (SWV) where changes in the reduction peak signal of ferrocyanide/ferricyanide redox couple can be observed due to the negatively charged aptamer's removal from the electrode surface upon target protein binding [64].

A fluorometric aptamer assay for detecting $\beta$-LG based on the use of magnetic nanoparticles and carbon dots as a signal indicator has been developed by Shi et al. [74]. The assay was based on the hybridization between aptamer, immobilization on magnetic nanoparticles, and the complementary oligonucleotide sequence labeled with carbon dots. In the presence of $\beta-L G$, the aptamer preferentially binds to the protein, and this binding leads to a partial release of the complementary sequence into the solution. After magnetic separation of the nanoparticles, the supernatant of the solution contained the released carbon dots, which were further quantified by fluorometry. The $\beta$-LG was measured in the $0.25 \times 10^{-3}$ to $50 \times 10^{-3} \mu \mathrm{g} / \mathrm{mL}$ range and an LOD of a $37 \times 10^{-6} \mu \mathrm{g} / \mathrm{mL}$ was achieved. This approach was successfully examined for sensing of $\beta$-LG in hypoallergenic formulations. 


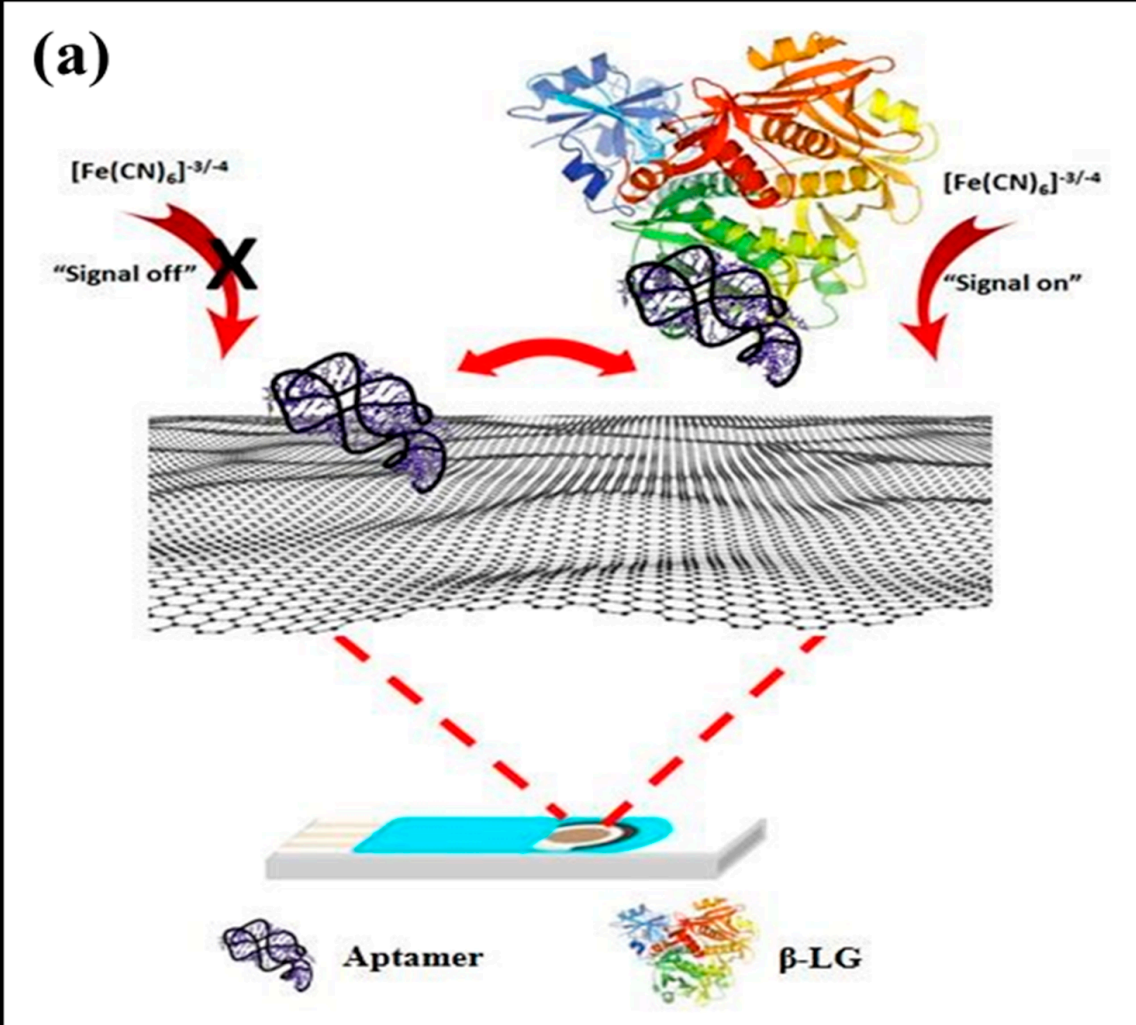

(b)

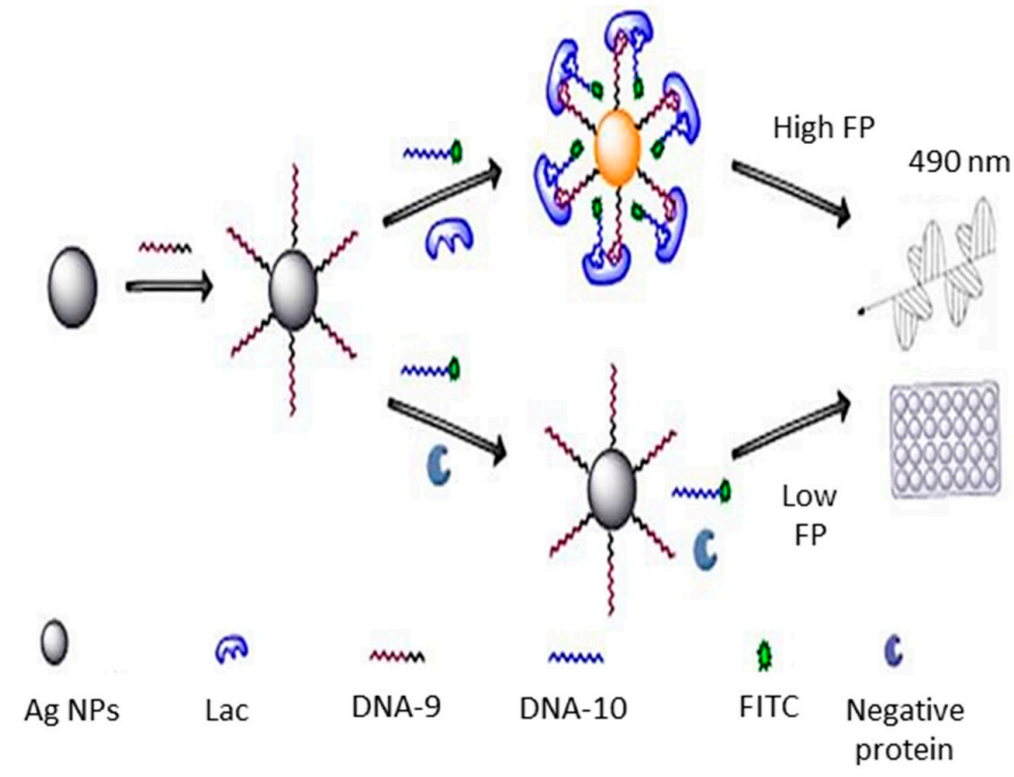

Figure 2. The most common aptasensors for milk allergens detection; (a) electrochemical detection of $\beta$-LG using aptamer-functionalized graphene screen-printed electrodes (reprinted with permission from ref. [64]) and (b) bivalent aptasensor using sliver decahedral nanoparticles for enhanced detection of lactoferrin in milk (reprinted with permission from ref. [77]). 
Further, highly specific $\beta$-LG-23 aptamer binding affinity to $\beta$-LG has been reported via enzyme linked apta-sorbent assay [75]. The proposed biosensor offered effective detection of $\beta$-LG with a LOD of $0.18 \mu \mathrm{g} / \mathrm{mL}$ or $10 \mathrm{nM}$ within $20 \mathrm{~min}$. The results are comparable to commercially available ELISA kit (provided by Crystal Chem) that has an LOD of $0.31 \times 10^{3} \mu \mathrm{g} / \mathrm{mL}$ with a $3 \mathrm{~h}$ assay time.

A novel bivalent aptasensor based on fluorescence polarization has been reported for lactoferrin detection by Chen et al. [77]. The fluorescence polarization is an effective technique where high sensitivity to the rate of rotation can be achieved by target-induced conformational or structural changes. In this aptasensor, two split aptamers were verified and modified to link with fluorescein isothiocyanate dye molecules and silver decahedral nanoparticles (working as enhancer), respectively (Figure 2). The aptamers, upon binding with lactoferrin, form a split aptamers-target complex that narrow down the distance between the dye and silver nanoparticles. In this case, mass-augment and also an enhanced fluorescence effect can be observed due to silver decahedral nanoparticles. In comparison to traditional aptamer-based homogeneous assays, the bivalent aptasensor offered a sensitivity three times higher with a LOD of $1.25 \mathrm{pM}$ for lactoferrin in milk powder.

Further, paper-based microfluidic devices are gaining considerable attention for point-of-care (POC) testing [123]. These devices are based on natural capillary action of cellulose substrate in order to perform the diagnostic test. Tah et al. [78] reported the conjugation of aptamers to gold nanoparticles and the utilized graphene oxide with a paper-based microfluidic device. Here, the functionalized gold nanoparticles offered a bridging effect between different layers of graphene oxide via pi-pi stacking that can be due to the gold nanoparticles-conjugated ssDNA aptamer. The microfluidic platform offered high sensitivity for colorimetric detection of $\beta$-LG with a LOD of $12.4 \mathrm{nM}$. The microfluidic platform has the potential for low-cost, rapid, and accurate POC device for real-time detection of milk allergens. Beyond these, several works have been reported on aptamer-based detection of pesticide residues [124], antibiotics [125-127], and others [128] from milk samples. However, there is still need to screen aptamers for other milk allergens, e.g., casein [55].

\section{Commercially Available Biosensors}

The biggest challenge for milk allergens detection is the lack of highly sensitive, low-cost, and user-friendly detection kits in the market. In order to ensure the milk safety from toxic substances and allergens, the user-friendly detection kits should be commercially available for use by individual consumers, food manufacturers, and food safety organizations. In the market, the available major milk allergens kits are as (i) ELISA kits such as Beta-lactoglobulin ELISA-Type II by Crystal Chem [129], SENSISpec Beta-Lactoglobulin ELISA kit by Eurofins Technologies [130], RIDASCREEN ${ }^{\circledR}$ FAST Milk by R Biopharma [131], etc. and (ii) lateral flow-based immunochromatic test kits such as AgraStrip ${ }^{\circledR}$ Total Milk by Romer Labs [132], Neogen's Reveal 3-D [133], Lateral Flow Milch/Milk by R-Biopharm AG [134], AlerTox Sticks Total Milk by Emport LLC [135], Charm Aller-ROSA Milk Test [136], etc. Several activities have been initiated for commercialization of biosensors with capabilities for detection of multiplexed allergens. For example, SensoGenic Pvt. Ltd., Israel is developing portable and digital diagnosis-based biosensors for allergens detection from food matrices (i.e., peanuts, milk, tree nuts, soy, fish, eggs, shellfish, and wheat) [137]. Currently, the transfer of biosensors from lab scale to commercial market is hampered by several limitations in terms of stability of biological receptors and costly development of biological sensing layers. Research activities for artificial receptors (such as aptamers) have been initiated but still only a limited number of aptamers have been screened for target analytes. Further, the incorporation of nanomaterials in biosensors has led to improved selectivity, sensitivity, high sample throughput, rapid analysis, and better efficiency in analysis from complex sample matrices than conventional analytical approaches. The combination of biomolecules with nanomaterials with novel characteristics showed immense potential for development of real-time, miniaturized, portable, cost-effective, and rapid biosensors possessing capabilities for detection of multiple allergens. These ongoing advancements in highly sensitive, accurate, low-cost, and easy to 
use biosensors are significant for quality control as well as food safety regulation. These biosensors are expected to become available in market from laboratory research in coming years.

\section{Conclusions and Future Prospects}

In order to protect the sensitized individuals to cow' milk allergens, the development of highly sensitive, selective, and accurate detection methods is necessary. Recently, biosensors (i.e., immunosensors and aptasensors) in combination with novel nanomaterials and sensing platform fabrication are offering a cheaper, facile, rapid, and multiplex detection of milk allergens in comparison to conventional techniques like ELISA, LC-MS, and real-time PCR. Here, we reviewed the considerable developments in both immunosensors and aptasensors for milk allergens detection. Besides significant potential of immunosensors in milk allergens detection, the major challenges in terms of instability and high cost of antibodies still need to be resolved. Although the highly specific reactivity of aptamers can resolve the issue of cross reactivity of detectors, the effect of variability of allergens presentation from different species on detection approach needs to be examined. The aptasensors for detection of milk allergens are in preliminary stage of development and still possess a long way to go for more acceptable diagnostic tool with high stability. The ongoing research for the development of new biosensors or biosensing kits is of paramount importance to reduce the gap between research at lab scale and the commercial applications.

Funding: This research was supported by Italian Government in the framework of PRIN 2017, Prot. 2017 YER72 K_005. SK thanks HSCST, Govt. of Haryana, India (research grant vide letter No. HSCST/R\&D/2018/2103 dated 01-08-2018).

Conflicts of Interest: Authors declare no conflict of interest.

\section{References}

1. Minh Hiep, H.; Endo, T.; Kerman, K.; Chikae, M.; Kim, D.K.; Yamamura, S.; Takamura, Y.; Tamiya, E. A localized surface plasmon resonance based immunosensor for the detection of casein in milk. Sci. Technol. Adv. Mater. 2007, 8, 331-338. [CrossRef]

2. Renz, H.; Allen, K.J.; Sicherer, S.H.; Sampson, H.A.; Lack, G.; Beyer, K.; Oettgen, H.C. Food allergy. Nat. Rev. Dis. Primers 2018, 4, 17098. [CrossRef] [PubMed]

3. Food Allergy World Allergy Organization. Available online: https://www.worldallergy.org/education-andprograms/education/allergic-disease-resource-center/professionals/food-allergy (accessed on 6 December 2019).

4. Williams, P.V. The epidemiology of milk allergy in US children. Pediatrics 2013, 132, S17-S18. [CrossRef]

5. Fiocchi, A.; Schünemann, H.J.; Brozek, J.; Restani, P.; Beyer, K.; Troncone, R.; Martelli, A.; Terracciano, L.; Bahna, S.L.; Rancé, F.; et al. Diagnosis and rationale for action against Cow's milk allergy (DRACMA): A summary report. J. Allergy Clin. Immunol. 2010, 126, 1119. [CrossRef] [PubMed]

6. Boyce, J.A.; Assa'ad, A.; Burks, A.W.; Jones, S.M.; Sampson, H.A.; Wood, R.A.; Plaut, M.; Cooper, S.F.; Fenton, M.J. Guidelines for the diagnosis and management of food allergy in the United States: Report of the NIAID-sponsored expert panel. J. Allergy Clin. Immunol. 2010, 126, S1-S58. [CrossRef] [PubMed]

7. Villa, C.; Costa, J.; Oliveira, M.B.P.P.; Mafra, I. Bovine Milk Allergens: A comprehensive review. Compr. Rev. Food Sci. Food Saf. 2018, 17, 137-164. [CrossRef]

8. Hochwallner, H.; Schulmeister, U.; Swoboda, I.; Spitzauer, S.; Valenta, R. Cow's milk allergy: From allergens to new forms of diagnosis, therapy and prevention. Methods 2014, 66, 22-33. [CrossRef]

9. Allergome. Available online: http://www.allergome.org/script/statistic.php (accessed on 22 November 2019).

10. Szépfalusi, Z.; Loibichler, C.; Pichler, J.; Reisenberger, K.; Ebner, C.; Urbanek, R. Direct evidence for transplacental allergen transfer. Pediatr. Res. 2000, 48, 404-407. [CrossRef]

11. D’Urbano, L.E.; Pellegrino, K.; Artesani, M.C.; Donnanno, S.; Luciano, R.; Riccardi, C.; Tozzi, A.E.; Ravà, L.; De Benedetti, F.; Cavagni, G. Performance of a component-based allergen-microarray in the diagnosis of cow's milk and hen's egg allergy. Clin. Exp. Allergy 2010, 40, 1561-1570. [CrossRef]

12. WHO/IUIS Allergen Nomenclature Home Page. Available online: http://www.allergen.org/ (accessed on 7 December 2019). 
13. Schulmeister, U.; Hochwallner, H.; Swoboda, I.; Focke-Tejkl, M.; Geller, B.; Nystrand, M.; Harlin, A.; Thalhamer, J.; Scheiblhofer, S.; Keller, W.; et al. Cloning, expression, and mapping of allergenic determinants of S1-casein, a major cow's milk allergen. J. Immunol. 2009, 182, 7019-7029. [CrossRef]

14. Kontopidis, G.; Holt, C.; Sawyer, L. Invited review: $\beta$-lactoglobulin: Binding properties, structure, and function. J. Dairy Sci. 2004, 87, 785-796. [CrossRef]

15. Adams, J.J.; Anderson, B.F.; Norris, G.E.; Creamer, L.K.; Jameson, G.B. Structure of bovine $\beta$-lactoglobulin (variant A) at very low ionic strength. J. Struct. Biol. 2006, 154, 246-254. [CrossRef] [PubMed]

16. Wal, J.-M. Bovine milk allergenicity. Ann. Allergy Asthma Immunol. 2004, 93, S2-S11. [CrossRef]

17. Tavares, G.M.; Croguennec, T.; Carvalho, A.F.; Bouhallab, S. Milk proteins as encapsulation devices and delivery vehicles: Applications and trends. Trends Food Sci. Technol. 2014, 37, 5-20. [CrossRef]

18. Van Neerven, R.J.J.; Knol, E.F.; Heck, J.M.L.; Savelkoul, H.F.J. Which factors in raw cow's milk contribute to protection against allergies? J. Allergy Clin. Immunol. 2012, 130, 853-858. [CrossRef] [PubMed]

19. Giblin, L.; Süha Yalçın, A.; Biçim, G.; Krämer, A.C.; Chen, Z.; Callanan, M.J.; Arranz, E.; Davies, M.J. Whey proteins: Targets of oxidation, or mediators of redox protection. Free Radic. Res. 2019, 1-17. [CrossRef]

20. Negaoui, H.; El Mecherfi, K.E.; Tadjer, S.A.; Grar, H.; Kheroua, O.; Saidi, D. Bovine lactoferrin allergenicity as studied in murine model of allergy. Food Agric. Immunol. 2016, 27, 711-723. [CrossRef]

21. D'Auria, E.; Salvatore, S.; Pozzi, E.; Mantegazza, C.; Sartorio, M.U.A.; Pensabene, L.; Baldassarre, M.E.; Agosti, M.; Vandenplas, Y.; Zuccotti, G. Cow's milk allergy: Immunomodulation by dietary intervention. Nutrients 2019, 11, 1399. [CrossRef]

22. D'Auria, E.; Mameli, C.; Piras, C.; Cococcioni, L.; Urbani, A.; Zuccotti, G.V.; Roncada, P. Precision medicine in cow's milk allergy: Proteomics perspectives from allergens to patients. J. Proteom. 2018, 188, 173-180. [CrossRef]

23. Linhart, B.; Freidl, R.; Elisyutina, O.; Khaitov, M.; Karaulov, A.; Valenta, R. Molecular approaches for diagnosis, therapy and prevention of cow's milk allergy. Nutrients 2019, 11, 1492. [CrossRef]

24. Faisal, M.; Vasiljevic, T.; Donkor, O.N. A review on methodologies for extraction, identification and quantification of allergenic proteins in prawns. Food Res. Int. 2019, 121, 307-318. [CrossRef] [PubMed]

25. Neethirajan, S.; Weng, X.; Tah, A.; Cordero, J.O.; Ragavan, K.V. Nano-biosensor platforms for detecting food allergens-New trends. Sens. Bio-Sens. Res. 2018, 18, 13-30. [CrossRef]

26. Croote, D.; Quake, S.R. Food allergen detection by mass spectrometry: The role of systems biology. npj Syst. Biol. Appl. 2016, 2. [CrossRef] [PubMed]

27. Mishra, G.K.; Sharma, V.; Mishra, R.K. Electrochemical aptasensors for food and environmental safeguarding: A review. Biosensors 2018, 8, 28. [CrossRef]

28. Alves, R.C.; Barroso, M.F.; González-García, M.B.; Oliveira, M.B.P.P.; Delerue-Matos, C. New trends in food allergens detection: Toward biosensing strategies. Crit. Rev. Food Sci. Nutr. 2016, 56, 2304-2319. [CrossRef]

29. Poms, R.E.; Klein, C.L.; Anklam, E. Methods for allergen analysis in food: A review. Food Addit. Contam. 2004, 21, 1-31. [CrossRef]

30. Acquah, C.; Agyei, D.; Obeng, E.M.; Pan, S.; Tan, K.X.; Danquah, M.K. Aptamers: An emerging class of bioaffinity ligands in bioactive peptide applications. Crit. Rev. Food Sci. Nutr. 2019, 1-12. [CrossRef]

31. Pilolli, R.; Monaci, L.; Visconti, A. Advances in biosensor development based on integrating nanotechnology and applied to food-allergen management. TrAC-Trends Anal. Chem. 2013, 47, 12-26. [CrossRef]

32. Fiocchi, A.; Schunemann, H.; Ansotegui, I.; Assa'ad, A.; Bahna, S.; Canani, R.B.; Bozzola, M.; Dahdah, L.; Dupont, C.; Ebisawa, M.; et al. The global impact of the DRACMA guidelines cow's milk allergy clinical practice. World Allergy Organ. J. 2018, 11, 2. [CrossRef]

33. Morisset, M.; Moneret-Vautrin, D.A.; Kanny, G.; Guenard, L.; Beaudouin, E.; Flabbee, J.; Hatahet, R. Thresholds of clinical reactivity to milk, egg, peanut and sesame in immunoglobulin E-dependent allergies: Evaluation by double-blind or single-blind placebo-controlled oral challenges. Clin. Exp. Allergy 2003, 33, 1046-1051. [CrossRef]

34. Verhoeckx, K.C.M.; Vissers, Y.M.; Baumert, J.L.; Faludi, R.; Feys, M.; Flanagan, S.; Herouet-Guicheney, C.; Holzhauser, T.; Shimojo, R.; van der Bolt, N.; et al. Food processing and allergenicity. Food Chem. Toxicol. 2015, 80, 223-240. [CrossRef] [PubMed]

35. Prado, M.; Ortea, I.; Vial, S.; Rivas, J.; Calo-Mata, P.; Barros-Velázquez, J. Advanced DNA- and protein-based methods for the detection and investigation of food allergens. Crit. Rev. Food Sci. Nutr. 2016, 56, 2511-2542. [CrossRef] [PubMed] 
36. Holzhauser, T. Protein or no protein? Opportunities for DNA-based detection of allergenic foods. J. Agric. Food Chem. 2018, 66, 9889-9894. [CrossRef] [PubMed]

37. Zeng, L.; Song, S.; Zheng, Q.; Luo, P.; Wu, X.; Kuang, H. Development of a sandwich ELISA and immunochromatographic strip for the detection of shrimp tropomyosin. Food Agric. Immunol. 2019, 30, 606-619. [CrossRef]

38. Orcajo, J.; Lavilla, M.; Martínez-de-Marañón, I. Specific and sensitive ELISA for measurement of IgE-binding variations of milk allergen $\beta$-lactoglobulin in processed foods. Anal. Chim. Acta 2019, 1052, 163-169. [CrossRef]

39. Samsonova, J.V.; Safronova, V.A.; Osipov, A.P. Rapid flow-through enzyme immunoassay of progesterone in whole cows' milk. Anal. Biochem. 2018, 545, 43-48. [CrossRef]

40. Chen, W.; Huang, Z.; Hu, S.; Peng, J.; Liu, D.; Xiong, Y.; Xu, H.; Wei, H.; Lai, W. Invited review: Advancements in lateral flow immunoassays for screening hazardous substances in milk and milk powder. J. Dairy Sci. 2019, 102, 1887-1900. [CrossRef]

41. Di Domenico, M.; Di Giuseppe, M.; Wicochea Rodríguez, J.D.; Cammà, C. Validation of a fast real-time PCR method to detect fraud and mislabeling in milk and dairy products. J. Dairy Sci. 2017, 100, 106-112. [CrossRef]

42. Villa, C.; Costa, J.; Oliveira, M.B.P.P.; Mafra, I. Cow's milk allergens: Screening gene markers for the detection of milk ingredients in complex meat products. Food Control 2020, 108, 106823. [CrossRef]

43. Ji, J.; Zhu, P.; Pi, F.; Sun, C.; Sun, J.; Jia, M.; Ying, C.; Zhang, Y.; Sun, X. Development of a liquid chromatography-tandem mass spectrometry method for simultaneous detection of the main milk allergens. Food Control 2017, 74, 79-88. [CrossRef]

44. Montowska, M.; Fornal, E. Detection of peptide markers of soy, milk and egg white allergenic proteins in poultry products by LC-Q-TOF-MS/MS. LWT 2018, 87, 310-317. [CrossRef]

45. Pastor-Vargas, C.; Maroto, A.S.; Díaz-Perales, A.; Villaba, M.; Casillas Diaz, N.; Vivanco, F.; Cuesta-Herranz, J. Sensitive detection of major food allergens in breast milk: First gateway for allergenic contact during breastfeeding. Allergy 2015, 70, 1024-1027. [CrossRef] [PubMed]

46. Standard Test May Miss Food Ingredients That Cause Milk Allergy-American Chemical Society. Available online: https://www.acs.org/content/acs/en/pressroom/newsreleases/2012/march/standard-test-may-missfood-ingredients-that-cause-milk-allergy.html (accessed on 15 October 2019).

47. Damodaran, S.; Li, Y. A two-step enzymatic modification method to reduce immuno-reactivity of milk proteins. Food Chem. 2017, 237, 724-732. [CrossRef] [PubMed]

48. Pessato, T.B.; de Carvalho, N.C.; Tavano, O.L.; Fernandes, L.G.R.; de L. Zollner, R.; Netto, F.M. Whey protein isolate hydrolysates obtained with free and immobilized Alcalase: Characterization and detection of residual allergens. Food Res. Int. 2016, 83, 112-120. [CrossRef]

49. Thevenot, D.R.; Tóth, K.; Durst, R.A.; Wilson, G.S. Electrochemical biosensors: Recommended definitions and classification. Pure Appl. Chem. 1999, 71, 2333-2348. [CrossRef]

50. Kumar, S.; Nehra, M.; Kedia, D.; Dilbaghi, N.; Tankeshwar, K.; Kim, K.-H. Nanodiamonds: Emerging face of future nanotechnology. Carbon N. Y. 2019, 143, 678-699. [CrossRef]

51. Nehra, M.; Dilbaghi, N.; Hassan, A.A. Carbon-Based Nanomaterials for the development of sensitive nanosensor platforms. Adv. Nanosens. Biol. Environ. Anal. 2019, 1-25. [CrossRef]

52. Zhang, Z.; Zhou, J.; Du, X. Electrochemical biosensors for detection of foodborne pathogens. Micromachines 2019, 10, 222. [CrossRef]

53. Saberi, R.S.; Shahrokhian, S.; Marrazza, G. Amplified electrochemical DNA sensor based on polyaniline film and gold nanoparticles. Electroanalysis 2013, 25, 1373-1380. [CrossRef]

54. Rashid, J.I.A.; Yusof, N.A. The strategies of DNA immobilization and hybridization detection mechanism in the construction of electrochemical DNA sensor: A review. Sens. Bio-Sens. Res. 2017, 16, 19-31. [CrossRef]

55. Vasilescu, A.; Nunes, G.; Hayat, A.; Latif, U.; Marty, J.L. Electrochemical affinity biosensors based on disposable screen-printed electrodes for detection of food allergens. Sensors 2016, 16, 1863. [CrossRef] [PubMed]

56. Restani, P.; Gaiaschi, A.; Plebani, A.; Beretta, B.; Cavagni, G.; Fiocchi, A.; Poiesi, C.; Velonà, T.; Ugazio, A.G.; Galli, C.L. Cross-reactivity between milk proteins from different animal species. Clin. Exp. Allergy 1999, 29, 997-1004. [CrossRef] [PubMed] 
57. Mehennaoui, S.; Poorahong, S.; Jimenez, G.C.; Siaj, M. Selection of high affinity aptamer-ligand for dexamethasone and its electrochemical biosensor. Sci. Rep. 2019, 9, 6600. [CrossRef] [PubMed]

58. Cao, Q.; Zhao, H.; Yang, Y.; He, Y.; Ding, N.; Wang, J.; Wu, Z.; Xiang, K.; Wang, G. Electrochemical immunosensor for casein based on gold nanoparticles and poly(l-Arginine)/multi-walled carbon nanotubes composite film functionalized interface. Biosens. Bioelectron. 2011, 26, 3469-3474. [CrossRef] [PubMed]

59. Indyk, H.E. Development and application of an optical biosensor immunoassay for $\alpha$-lactalbumin in bovine milk. Int. Dairy J. 2009, 19, 36-42. [CrossRef]

60. Indyk, H.E.; Filonzi, E.L. Determination of lactoferrin in bovine milk, colostrum and infant formulas by optical biosensor analysis. Int. Dairy J. 2005, 15, 429-438. [CrossRef]

61. Rebe Raz, S.; Liu, H.; Norde, W.; Bremer, M.G.E.G. Food allergens profiling with an imaging surface plasmon resonance-based biosensor. Anal. Chem. 2010, 82, 8485-8491. [CrossRef]

62. Ruiz-Valdepeñas Montiel, V.; Campuzano, S.; Torrente-Rodríguez, R.M.; Reviejo, A.J.; Pingarrón, J.M. Electrochemical magnetic beads-based immunosensing platform for the determination of $\alpha$-lactalbumin in milk. Food Chem. 2016, 213, 595-601. [CrossRef]

63. Hohensinner, V.; Maier, I.; Pittner, F. A "gold cluster-linked immunosorbent assay": Optical near-field biosensor chip for the detection of allergenic $\beta$-lactoglobulin in processed milk matrices. J. Biotechnol. 2007, 130, 385-388. [CrossRef]

64. Eissa, S.; Zourob, M. In vitro selection of DNA aptamers targeting $\beta$-lactoglobulin and their integration in graphene-based biosensor for the detection of milk allergen. Biosens. Bioelectron. 2017, 91, 169-174. [CrossRef]

65. Eissa, S.; Tlili, C.; L'Hocine, L.; Zourob, M. Electrochemical immunosensor for the milk allergen $\beta$-lactoglobulin based on electrografting of organic film on graphene modified screen-printed carbon electrodes. Biosens. Bioelectron. 2012, 38, 308-313. [CrossRef] [PubMed]

66. Billakanti, J.M.; Fee, C.J.; Lane, F.R.; Kash, A.S.; Fredericks, R. Simultaneous, quantitative detection of five whey proteins in multiple samples by surface plasmon resonance. Int. Dairy J. 2010, 20, 96-105. [CrossRef]

67. Ruiz-Valdepeñas Montiel, V.; Campuzano, S.; Conzuelo, F.; Torrente-Rodríguez, R.M.; Gamella, M.; Reviejo, A.J.; Pingarrón, J.M. Electrochemical magnetoimmunosensing platform for determination of the milk allergen $\beta$-lactoglobulin. Talanta 2015, 131, 156-162. [CrossRef] [PubMed]

68. Ashley, J.; D’Aurelio, R.; Piekarska, M.; Temblay, J.; Pleasants, M.; Trinh, L.; Rodgers, T.L.; Tothill, I.E. Development of a $\beta$-Lactoglobulin sensor based on SPR for milk allergens detection. Biosensors 2018, 8, 32. [CrossRef] [PubMed]

69. Álvarez, J.; Sola, L.; Cretich, M.; Swann, M.J.; Gylfasson, K.B.; Volden, T.; Chiari, M.; Hill, D. Real time optical immunosensing with flow-through porous alumina membranes. Sens. Actuators B Chem. 2014, 202, 834-839. [CrossRef]

70. Wu, X.; Li, Y.; Liu, B.; Feng, Y.; He, W. Two-site antibody immunoanalytical detection of food allergens by surface plasmon resonance. Food Anal. Methods 2016, 9, 582-588. [CrossRef]

71. Yang, A.; Zheng, Y.; Long, C.; Chen, H.; Liu, B.; Li, X.; Yuan, J.; Cheng, F. Fluorescent immunosorbent assay for the detection of alpha lactalbumin in dairy products with monoclonal antibody bioconjugated with CdSe/ZnS quantum dots. Food Chem. 2014, 150, 73-79. [CrossRef]

72. Kokkinos, C.; Angelopoulou, M.; Economou, A.; Prodromidis, M.; Florou, A.; Haasnoot, W.; Petrou, P.; Kakabakos, S. Lab-on-a-membrane foldable devices for duplex drop-volume electrochemical biosensing using quantum dot tags. Anal. Chem. 2016, 88, 6897-6904. [CrossRef]

73. Jiang, D.; Ge, P.; Wang, L.; Jiang, H.; Yang, M.; Yuan, L.; Ge, Q.; Fang, W.; Ju, X. A novel electrochemical mast cell-based paper biosensor for the rapid detection of milk allergen casein. Biosens. Bioelectron. 2019, 130, 299-306. [CrossRef]

74. Shi, M.; Cen, Y.; Sohail, M.; Xu, G.; Wei, F.; Ma, Y.; Xu, X.; Ma, Y.; Song, Y.; Hu, Q. Aptamer based fluorometric $\beta$-lactoglobulin assay based on the use of magnetic nanoparticles and carbon dots. Microchim. Acta 2018, 185, 1-8. [CrossRef]

75. Clemente, A.P.B.; Kuang, H.; Shabana, A.M.; Labuza, T.P.; Kokkoli, E. Design of an aptamer-amphiphile for the detection of $\beta$-lactoglobulin on a liquid crystal interface. Bioconjug. Chem. 2019, 30, 2763-2770. [CrossRef] [PubMed]

76. Lettieri, M.; Hosu, O.; Adumitrachioaie, A.; Cristea, C.; Marrazza, G. Beta-lactoglobulin electrochemical detection based with an innovative platform based on composite polymer. Electroanalysis 2019. [CrossRef] 
77. Chen, Z.; Li, H.; Jia, W.; Liu, X.; Li, Z.; Wen, F.; Zheng, N.; Jiang, J.; Xu, D. Bivalent aptasensor based on silver-enhanced fluorescence polarization for rapid detection of lactoferrin in milk. Anal. Chem. 2017, 89, 5900-5908. [CrossRef] [PubMed]

78. Tah, A.; Cordero, J.M.O.; Weng, X.; Neethirajan, S. Aptamer-based biosensor for food allergen determination using graphene oxide/gold nanocomposite on a paper-assisted analytical device. bioRxiv 2018, 343368. [CrossRef]

79. Felix, F.S.; Angnes, L. Electrochemical immunosensors-A powerful tool for analytical applications. Biosens. Bioelectron. 2018, 102, 470-478. [CrossRef] [PubMed]

80. Cho, I.-H.; Lee, J.; Kim, J.; Kang, M.; Paik, J.; Ku, S.; Cho, H.-M.; Irudayaraj, J.; Kim, D.-H. Current technologies of electrochemical immunosensors: Perspective on signal amplification. Sensors 2018, 18, 207. [CrossRef]

81. Rynne, N.M.; Beresford, T.P.; Kelly, A.L.; Guinee, T.P. Effect of milk pasteurization temperature and in situ whey protein denaturation on the composition, texture and heat-induced functionality of half-fat Cheddar cheese. Int. Dairy J. 2004, 14, 989-1001. [CrossRef]

82. Jackman, J.A.; Cho, N.J.; Nishikawa, M.; Yoshikawa, G.; Mori, T.; Shrestha, L.K.; Ariga, K. Materials Nanoarchitectonics for Mechanical Tools in Chemical and Biological Sensing. Chem.-Asian J. 2018, 13, 3366-3377. [CrossRef]

83. Yun, Y.; Pan, M.; Wang, L.; Li, S.; Wang, Y.; Gu, Y.; Yang, J.; Wang, S. Fabrication and evaluation of a label-free piezoelectric immunosensor for sensitive and selective detection of amantadine in foods of animal origin. Anal. Bioanal. Chem. 2019, 411, 5745-5753. [CrossRef]

84. Marrazza, G. Piezoelectric biosensors for organophosphate and carbamate pesticides: A review. Biosensors 2014, 4, 301-317. [CrossRef]

85. Khansili, N.; Rattu, G.; Krishna, P.M. Label-free optical biosensors for food and biological sensor applications. Sens. Actuators B Chem. 2018, 265, 35-49. [CrossRef]

86. Lu, Y.; Shi, Z.; Liu, Q. Smartphone-based Biosensors for Portable Food Evaluation. Curr. Opin. Food Sci. 2019, 28, 74-81. [CrossRef]

87. Steglich, P.; Hülsemann, M.; Dietzel, B.; Mai, A. Optical biosensors based on silicon-on-insulator ring resonators: A review. Molecules 2019, 24, 519. [CrossRef] [PubMed]

88. Daems, D.; Lu, J.; Delport, F.; Mariën, N.; Orbie, L.; Aernouts, B.; Adriaens, I.; Huybrechts, T.; Saeys, W.; Spasic, D.; et al. Competitive inhibition assay for the detection of progesterone in dairy milk using a fiber optic SPR biosensor. Anal. Chim. Acta 2017, 950, 1-6. [CrossRef] [PubMed]

89. Zhou, J.; Qi, Q.; Wang, C.; Qian, Y.; Liu, G.; Wang, Y.; Fu, L. Surface plasmon resonance (SPR) biosensors for food allergen detection in food matrices. Biosens. Bioelectron. 2019, 142, 111449. [CrossRef] [PubMed]

90. Ashley, J.; Piekarska, M.; Segers, C.; Trinh, L.; Rodgers, T.; Willey, R.; Tothill, I.E. An SPR based sensor for allergens detection. Biosens. Bioelectron. 2017, 88, 109-113. [CrossRef]

91. Indyk, H.E.; Hart, S.; Meerkerk, T.; Gill, B.D.; Woollard, D.C. The $\beta$-lactoglobulin content of bovine milk: Development and application of a biosensor immunoassay. Int. Dairy J. 2017, 73, 68-73. [CrossRef]

92. Scarano, S.; Scuffi, C.; Mascini, M.; Minunni, M. Surface Plasmon Resonance imaging-based sensing for anti-bovine immunoglobulins detection in human milk and serum. Anal. Chim. Acta 2011, 707, 178-183. [CrossRef]

93. Kosaka, P.M.; Pini, V.; Ruz, J.J.; da Silva, R.A.; González, M.U.; Ramos, D.; Calleja, M.; Tamayo, J. Detection of cancer biomarkers in serum using a hybrid mechanical and optoplasmonic nanosensor. Nat. Nanotechnol. 2014, 9, 1047-1053. [CrossRef]

94. Ricciardi, C.; Santoro, K.; Stassi, S.; Lamberti, C.; Gabriella, M.; Arlorio, M.; Decastelli, L. Microcantilever resonator arrays for immunodetection of $\beta$-lactoglobulin milk allergen. Sens. Actuators B Chem. 2018, 254, 613-617. [CrossRef]

95. Ruiz-Valdepeñas Montiel, V.; Povedano, E.; Benedé, S.; Mata, L.; Galán-Malo, P.; Gamella, M.; Reviejo, A.J.; Campuzano, S.; Pingarrón, J.M. Disposable amperometric immunosensor for the detection of adulteration in milk through single or multiplexed determination of bovine, ovine, or caprine immunoglobulins G. Anal. Chem. 2019, 91, 11266-11274. [CrossRef] [PubMed]

96. Reverté, L.; Prieto-Simón, B.; Campàs, M. New advances in electrochemical biosensors for the detection of toxins: Nanomaterials, magnetic beads and microfluidics systems. A review. Anal. Chim. Acta 2016, 908, 8-21. [CrossRef] [PubMed] 
97. Serafín, V.; Torrente-Rodríguez, R.M.; Batlle, M.; García de Frutos, P.; Campuzano, S.; Yáñez-Sedeño, P.; Pingarrón, J.M. Comparative evaluation of the performance of electrochemical immunosensors using magnetic microparticles and nanoparticles. Application to the determination of tyrosine kinase receptor AXL. Microchim. Acta 2017, 184, 4251-4258. [CrossRef]

98. Hernández-Neuta, I.; Neumann, F.; Brightmeyer, J.; Ba Tis, T.; Madaboosi, N.; Wei, Q.; Ozcan, A.; Nilsson, M. Smartphone-based clinical diagnostics: Towards democratization of evidence-based health care. J. Intern. Med. 2019, 285, 19-39. [CrossRef] [PubMed]

99. Vashist, S.K.; van Oordt, T.; Schneider, E.M.; Zengerle, R.; von Stetten, F.; Luong, J.H.T. A smartphone-based colorimetric reader for bioanalytical applications using the screen-based bottom illumination provided by gadgets. Biosens. Bioelectron. 2015, 67, 248-255. [CrossRef] [PubMed]

100. Zangheri, M.; Cevenini, L.; Anfossi, L.; Baggiani, C.; Simoni, P.; Di Nardo, F.; Roda, A. A simple and compact smartphone accessory for quantitative chemiluminescence-based lateral flow immunoassay for salivary cortisol detection. Biosens. Bioelectron. 2015, 64, 63-68. [CrossRef]

101. Zhang, D.; Liu, Q. Biosensors and bioelectronics on smartphone for portable biochemical detection. Biosens. Bioelectron. 2016, 75, 273-284. [CrossRef]

102. Hosu, O.; Ravalli, A.; Lo Piccolo, G.M.; Cristea, C.; Sandulescu, R.; Marrazza, G. Smartphone-based immunosensor for CA125 detection. Talanta 2017, 166, 234-240. [CrossRef]

103. Ross, G.M.S.; Bremer, M.G.E.G.; Nielen, M.W.F. Consumer-friendly food allergen detection: Moving towards smartphone-based immunoassays. Anal. Bioanal. Chem. 2018, 410, 5353-5371. [CrossRef]

104. Shahvar, A.; Saraji, M.; Shamsaei, D. Headspace single drop microextraction combined with mobile phone-based on-drop sensing for the determination of formaldehyde. Sens. Actuators B Chem. 2018, 273, 1474-1478. [CrossRef]

105. Ludwig, S.K.J.; Zhu, H.; Phillips, S.; Shiledar, A.; Feng, S.; Tseng, D.; Van Ginkel, L.A.; Nielen, M.W.F.; Ozcan, A. Cellphone-based detection platform for rbST biomarker analysis in milk extracts using a microsphere fluorescence immunoassay. Anal. Bioanal. Chem. 2014, 406, 6857-6866. [CrossRef] [PubMed]

106. Ludwig, S.K.J.; Tokarski, C.; Lang, S.N.; van Ginkel, L.A.; Zhu, H.; Ozcan, A.; Nielen, M.W.F. Calling biomarkers in milk using a protein microarray on your smartphone. PLoS ONE 2015, 10, e0134360. [CrossRef] [PubMed]

107. Molinari, J.; Moina, C.; Ybarra, G. Electrochemical immunosensor for the determination of $\beta$-casein. J. Electrochem. Sci. Eng. 2015, 5, 9-16. [CrossRef]

108. Jiang, D.; Zhu, P.; Jiang, H.; Ji, J.; Sun, X.; Gu, W.; Zhang, G. Fluorescent magnetic bead-based mast cell biosensor for electrochemical detection of allergens in foodstuffs. Biosens. Bioelectron. 2015, 70, 482-490. [CrossRef] [PubMed]

109. Angelopoulou, M.; Botsialas, A.; Salapatas, A.; Petrou, P.S.; Haasnoot, W.; Makarona, E.; Jobst, G.; Goustouridis, D.; Siafaka-Kapadai, A.; Raptis, I.; et al. Assessment of goat milk adulteration with a label-free monolithically integrated optoelectronic biosensor. Anal. Bioanal. Chem. 2015, 407, 3995-4004. [CrossRef] [PubMed]

110. Gómez-Arribas, L.N.; Benito-Peña, E.; Del Carmen Hurtado-Sánchez, M.; Moreno-Bondi, M.C. Biosensing based on nanoparticles for food allergens detection. Sensors 2018, 18, 1087. [CrossRef]

111. Li, Y.; Tang, S.; Zhang, W.; Cui, X.; Zhang, Y.; Jin, Y.; Zhang, X.; Chen, Y. A surface-enhanced Raman scattering-based lateral flow immunosensor for colistin in raw milk. Sens. Actuators B Chem. 2019, 703-711. [CrossRef]

112. Castillo, D.S.; Cassola, A. Novel sensitive monoclonal antibody based competitive enzyme-linked immunosorbent assay for the detection of raw and processed bovine beta-casein. PLoS ONE 2017, 12, e0182447. [CrossRef]

113. Toh, S.Y.; Citartan, M.; Gopinath, S.C.B.; Tang, T.-H. Aptamers as a replacement for antibodies in enzyme-linked immunosorbent assay. Biosens. Bioelectron. 2015, 64, 392-403. [CrossRef]

114. Khedri, M.; Ramezani, M.; Rafatpanah, H.; Abnous, K. Detection of food-born allergens with aptamer-based biosensors. TrAC Trends Anal. Chem. 2018, 103, 126-136. [CrossRef]

115. Jauset-Rubio, M.; El-Shahawi, M.S.; Bashammakh, A.S.; Alyoubi, A.O.; O'Sullivan, C.K. Advances in aptamers-based lateral flow assays. TrAC-Trends Anal. Chem. 2017, 97, 385-398. [CrossRef]

116. Malekzad, H.; Jouyban, A.; Hasanzadeh, M.; Shadjou, N.; de la Guardia, M. Ensuring food safety using aptamer based assays: Electroanalytical approach. TrAC Trends Anal. Chem. 2017, 94, 77-94. [CrossRef] 
117. Vasilescu, A.; Marty, J.-L. Electrochemical aptasensors for the assessment of food quality and safety. $\operatorname{Tr} A C$ Trends Anal. Chem. 2016, 79, 60-70. [CrossRef]

118. Sassolas, A.; Blum, L.J.; Béatrice, D.L.B. Electrochemical aptasensors. Electroanalysis 2009, 21, 1237-1250. [CrossRef]

119. Yu, F.; Li, H.; Sun, W.; Zhao, Y.; Xu, D.; He, F. Selection of aptamers against Lactoferrin based on silver enhanced and fluorescence-activated cell sorting. Talanta 2019, 193, 110-117. [CrossRef]

120. Liu, X.; Li, H.; Jia, W.; Chen, Z.; Xu, D. Selection of aptamers based on a protein microarray integrated with a microfluidic chip. Lab Chip 2017, 17, 178-185. [CrossRef]

121. Zhang, Y.; Wu, Q.; Sun, M.; Zhang, J.; Mo, S.; Wang, J.; Wei, X.; Bai, J. Magnetic-assisted aptamer-based fluorescent assay for allergen detection in food matrix. Sens. Actuators B Chem. 2018, 263, 43-49. [CrossRef]

122. Frohnmeyer, E.; Tuschel, N.; Sitz, T.; Hermann, C.; Dahl, G.T.; Schulz, F.; Baeumner, A.J.; Fischer, M. Aptamer lateral flow assays for rapid and sensitive detection of cholera toxin. Analyst 2019, 144, 1840-1849. [CrossRef]

123. Kumar, S.; Nehra, M.; Mehta, J.; Dilbaghi, N.; Marrazza, G.; Kaushik, A. Point-of-care strategies for detection of waterborne pathogens. Sensors 2019, 19, 4476. [CrossRef]

124. Verdian, A. Apta-nanosensors for detection and quantitative determination of acetamiprid-A pesticide residue in food and environment. Talanta 2018, 176, 456-464. [CrossRef]

125. Javidi, M.; Housaindokht, M.R.; Verdian, A.; Razavizadeh, B.M. Detection of chloramphenicol using a novel apta-sensing platform based on aptamer terminal-lock in milk samples. Anal. Chim. Acta 2018, 1039, 116-123. [CrossRef] [PubMed]

126. Wang, C.; Wang, C.; Wang, Q.; Chen, D. Resonance light scattering method for detecting kanamycin in milk with enhanced sensitivity. Anal. Bioanal. Chem. 2017, 409, 2839-2846. [CrossRef] [PubMed]

127. Luan, Q.; Gan, N.; Cao, Y.; Li, T. Mimicking an Enzyme-Based Colorimetric Aptasensor for Antibiotic Residue Detection in Milk Combining Magnetic Loop-DNA Probes and CHA-Assisted Target Recycling Amplification. J. Agric. Food Chem. 2017, 65, 5731-5740. [CrossRef] [PubMed]

128. Qiu, Y.; Tang, Y.; Li, B.; Gu, C.; He, M. Aptamer-based detection of melamine in milk using an evanescent wave fiber sensor. Anal. Methods 2018, 10, 4871-4878. [CrossRef]

129. Beta-Lactoglobulin ELISA Kit II, Milk Allergen Kit | Crystal Chem. Available online: http://www.crystalchem. com/beta-lactoglobulin-elisa-kit.html (accessed on 19 October 2019).

130. SENSISpec Spike Solution Beta-Lactoglobulin. Available online: https://www.eurofins-technologies.com/ sensispec-spike-solution-beta-lactoglobulin.html (accessed on 19 October 2019).

131. RIDASCREEN ${ }^{\circledR}$ FAST Milk (en)- Food \& Feed Analysis. Available online: https://food.r-biopharm.com/ products/ridascreenfast-milk/ (accessed on 22 November 2019).

132. AgraStrip ${ }^{\circledR}$ Total Milk. Available online: https://www.romerlabs.com/shop/inter_en/agrastrip-r-total-milk/ \#theme.catalog.product.additional.information.documents.detailed (accessed on 19 October 2019).

133. Reveal 3-D Food Allergen Test Strips | Food Safety | Neogen. Available online: https://foodsafety.neogen. com/en/reveal-3-d (accessed on 19 October 2019).

134. Lateral Flow Milk (en)- Food \& Feed Analysis. Available online: https:/food.r-biopharm.com/products/ lateral-flow-milk/ (accessed on 19 October 2019).

135. AlerTox Sticks Total Milk: Rapid testing for Anitgens. Available online: https://emportllc.com/product/ alertox-total-milk/ (accessed on 19 October 2019).

136. Aller-ROSA-Charm Sciences. Available online: https://www.charm.com/products/test-and-kits/allergentests/aller-rosa/ (accessed on 19 October 2019).

137. About Us-Sensogenic. Available online: http://www.sensogenic.com/about-us/ (accessed on 22 November 2019).

(C) 2019 by the authors. Licensee MDPI, Basel, Switzerland. This article is an open access article distributed under the terms and conditions of the Creative Commons Attribution (CC BY) license (http://creativecommons.org/licenses/by/4.0/). 